\title{
LA-7972-MS
}

Informal Report

3

CIC-14 REPORT COLLECTION

REPRODUCTION

COPY

\section{LASL Fabrication Flowsheet for GPHS Fuel Pellets}

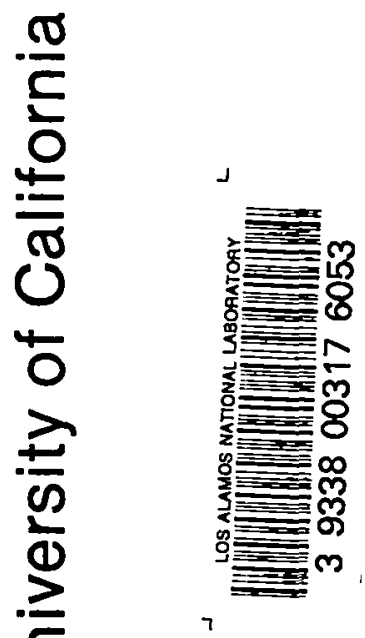


An Affirmative Action/Equal Opportunity Employer

This report was not edited by the Technical Information staff.

This work was supported by the US Department of Energy, Division of Advanced Nuclear Systems and Projects.

This report was prepared as an aceounc of work spunsored by the United States Government. Nelther the United Stutes nor the Unlted States Department of Enerev. noe any of their employees, nor any of their contractors, subcontzactors, or their employees, makes uny warmaniy. express or implied. or assumes any lezal liabuhy or resoonsibiling for the aceuracy. completeness. or uselulness of any information. apparalus. pot infringe privately owned rithts. 


\title{
LASL Fabrication Flowsheet for
}

\section{GPHS Fuel Pellets}

\author{
R. A. Kent
}

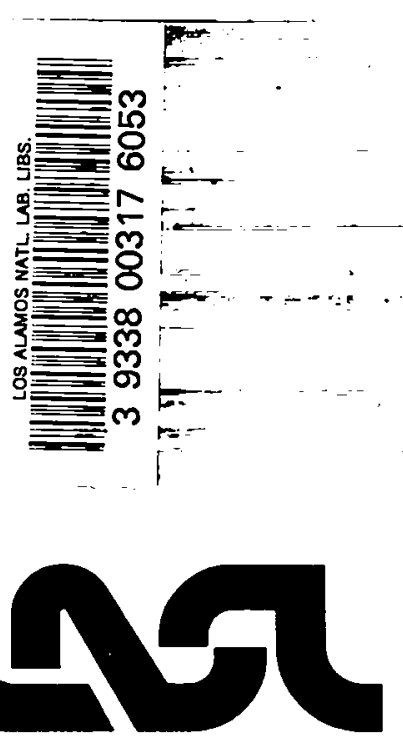




\title{
LASL FABRICATION FLOWSHEET \\ FOR GPHS FUEL PELLETS
}

\author{
by
}

R. A. Kent

\begin{abstract}
The General Purpose Heat Source (GPHS) being developed by the Los ATamos Scientific Laboratory for the Department of Energy, Division of Advanced Nuclear Systems and Projects, consists of a series of graphite modules, each having a thermal power inventory of 62.5 watts. Each module is loaded with four cylindrical $62.5-\mathrm{W}^{238} \mathrm{PuO}_{2}$ fuel pellets. This report summarizes the specifications for these pellets together with the fabrication flowsheet developed at LASL.
\end{abstract}

\section{INTRODUCTION}

The Los Alamos Scientific Laboratory (LASL) has been involved for a number of years in a continuing program to develop and characterize ${ }^{238} \mathrm{PuO}_{2}$ fuel forms used in radioisotopic thermal-electric generators (RTGS) to provide electric power for spacecraft. Once a specific fuel form has been selected and characterized, the LASL fabrication parameters and flowsheets are generally transferred to another Department of Energy (DOE) contractor for production. Previously, LASL supplied fabrication information to Mounds Facility (MF) for the plutonia-molybdenum-cermet fuel form (PMC) used in the PIONEER, TRANSIT, and VIKING missions and for the 100-W spherical plutonia fuel form (MHW) used in the LES and VOYAGER missions. Subsequently, LASL supplied fabrication information to the Savannah River Plant and Laboratory (SRP and SRL) for the improved MHW fuel form to be used for the GALILEO mission.

In addition to developing and characterizing specific fuel forms, LASL has been involved in a long range developmental program to determine the effects of fabrication parameters on fuel microstructures and, in turn, the effects of microstructural changes on fuel properties.

The flowsheet, discussed below, for the fabrication of ${ }^{238} \mathrm{PuO}_{2}$ GPHS fuel pellets is the result of the experience gained at LASL, both in the developmental program -4 and in the continuing development and characterization of specific fuel forms. 5 The initial version of this flowsheet was presented at 
DOE headquarters by R. W. Zocher in July, 1978 and a slightly amended version was presented by S. E. Bronisz in April, 1979. Each step in the flowsheet, including modifications, has been discussed in detail in meetings between LASL and SRP/SRL personnel. The final version of the flowsheet, presented in this report, was modified slightly based on the LASL experience in fabricating nearly thirty GPHS pellets for the design-phase impact test series.

\section{FUEL FORM DESCRIPTION AND DEVELOPMENT}

The selected GPHS fuel form is shown in Fig. 1 and consists of a right circular cylinder with radiused endcaps and a thermal inventory of 62.5 watts. The dimensions for the endcaps were selected to duplicate the thickness/radiusof-curvature ratio for the iridium container. The fuel pellet is fabricated by hot pressing 152.44 of LASL GROG-type feed, a mixture of $<125-\mu \mathrm{m} 238 \mathrm{PuO}_{2}$ granules seasoned at $11000^{\circ} \mathrm{C}(60 \mathrm{wt} \%)$ and $1600^{\circ} \mathrm{C}(40 \mathrm{wt} \%)$. The radiused endcaps are formed during hot pressing and no machining of the pellet is required. After hot pressing, the pellet is sintered for $6 \mathrm{~h}$ at $1527^{\circ} \mathrm{C}$ to stabilize the microstructure and produce the desired grain size, 20-30 $\mu \mathrm{m}$. Granule seasoning and pellet sintering operations are performed in an oxygen-16 atmosphere to reduce the neutron emission rate due to $(\alpha, n)$ reactions with the 170 and 180 isotopes present in normal oxygen. The as-pressed pellet has a centerline diameter of $27.78 \mathrm{~mm}$ and a centerline length of $27.88 \mathrm{~mm}$. During the subsequent post-press sintering, these dimensions will usually shrink 0.5 to 0.8 percent resulting in a pellet density of about $85 \%$ TD.

Four assumptions and constraints, based on the LASL experience gained in fuel form development and in the long range developmental studies, were applied to the development of the GPHS fuel form. These were (a) the fuel would consist of pure plutonium oxide (PPO). (b) the fuel density would be in the range 80 to 86 percent of theoretical density (TO), (c) the thermal inventory per individual fuel form would be greater than 15 watts but less than 100 watts and (d) the fuel would have a better impact response than MHW fuel. The density range was set to ensure a density equal to or greater than that for MHI fuel, but low enough to limit problems associated with helium release. The thermal inventory range was set to produce a reasonable power density and clad/fuel weight ratio while providing a fuel with lower thermal gradients, and consequent thermal stresses, than those for MHW fuel. The radiused endcaps are intended to eliminate thermal stress points and to enhance impact response.

Prior to the development of the GPHS fuel form, three types of fuel were fabricated and tested at LASL to determine the impact response. These consisted of high density pellets ( $86 \%$ TD), low density pellets (61\% TD), and particulate fuel with a 55\% packing density. Each type of fuel was sintered at the same temperature to eliminate grain size as a variable. The high density pellets, when impacted, proved to be siqnificantly stronger than the other types of fuel and, consequentiy, had a better impact response.

The results of additional developmental studies performed at LASL indicated that as fuel microstructures were made more uniform, the impact response improved. An early result of these studies was the development of the flowsheet for the fabrication of homogeneous MHW spheres. Three such spheres were made at LASL, sent to MF for encapsulation and returned to LASL for impact testing. Al1 three spheres survived the usual MHW impact test. The fabrication flowsheet for these spheres was transferred from LASL to SRP in 1977. 


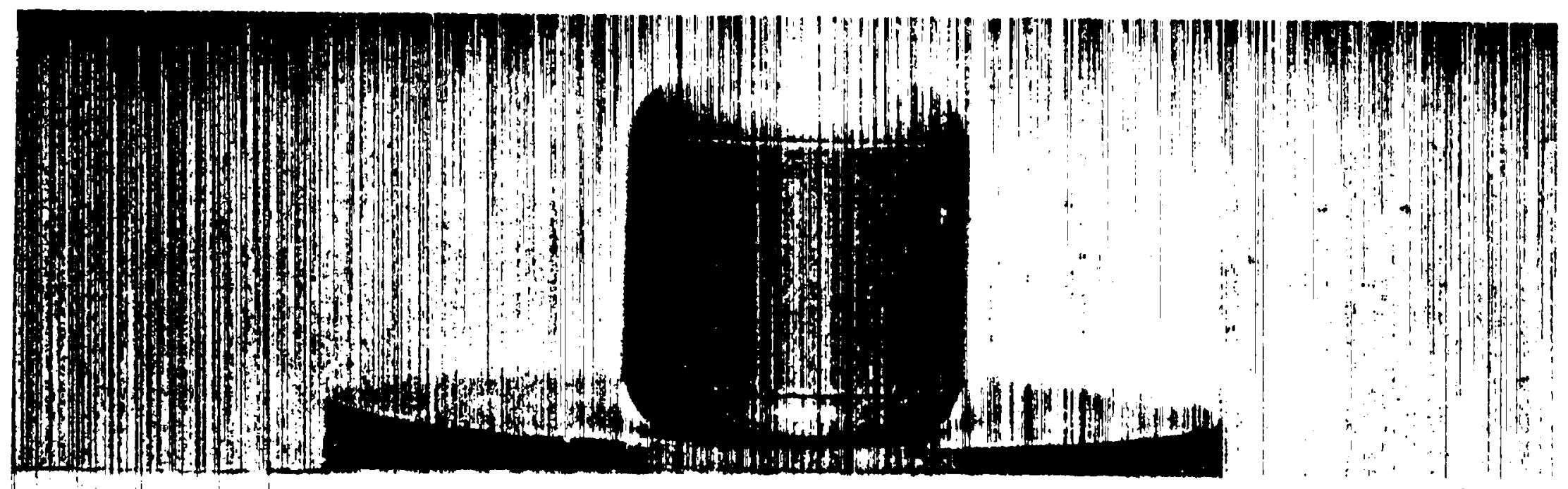

$$
\text { LASIL GH..25 }
$$

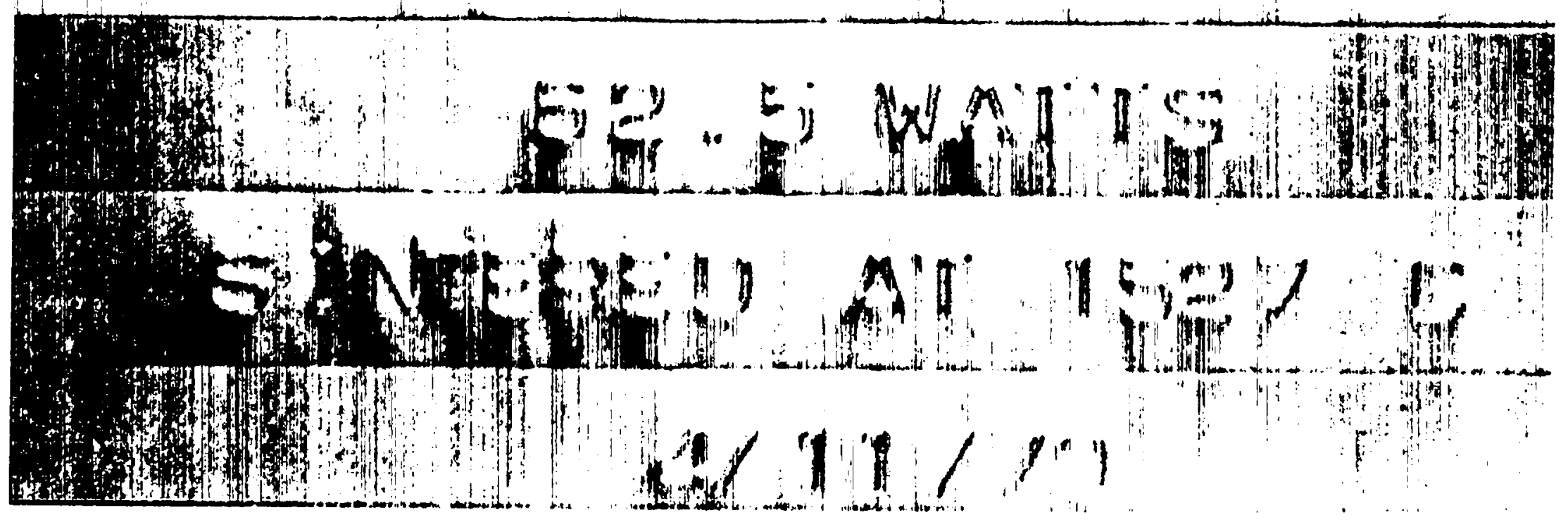

Fig. 1. Sintered LASL 62.5-W GPHS pellet. 
The results of subsequent LASL developmental studies indicated that further improvements in microstructural homogeneity could be obtained with the use of GROG-type feed. This consists of a mixture of relatively nonreactive granules, seasoned at a high temperature, and more active granules seasoned at a lower temperature. The nonreactive granules form a microstructural skeleton, around which the more active granules form during pressing and post-press sintering. An example of the microstructural improvement obtained with the GROG-type feed is shown in Figs. 2 and 3 . The cross sections shown in Fig. 2 are for pellets made with non-GROG-type feed granules. The internal crack pattern, due to shrinkage during sintering, is clearly evident. The cross sections shown in Fig. 3 are for pellets made in the same manner except that GROG-type feed was substituted. The absence of internal cracks means that the pellet made with the GROG-type feed will have a stronger microstructure and, consequentiy, a better impact response.

Three fuel forms were selected for the Conceptial and Trial Design Phases. These were (a) 62.5-W pellets as shown in Fig. 1, (b) similarly shaped 33.3-W pellets, and (c) $62.5-\mathrm{W}$ spheres. The fabrication feasibility and parameters were established for each. In addition, a number of 17.4-W pel lets were fabricated for the initial GPHS impact tests. These pellets had the same density, microstructure and diameter/length ratio as the $62.5-\mathrm{W}$ pellets. The smaller size was selected for the initial impact tests to conserve the platinum and iridium container alloys which were in short supply.

Finally, the 62.5-W pellet was selected, primarily on the basis of power density. Approximately 30 pellets of the tyoe shown in Fig. 1 have been fabricated in the new LASL Plutonium Facility. To date, 14 LASL 62.5-W GPHS pellets, made with GROG-type feed, have been encapsulated and 12 have been impacted, each one successfully.

Metallographic results for a 62.5-W GPHS pellet are shown in Fig. 4 and indicate the homogeneous distribution of the microstructural porosity.

\section{I. FUEL COMPOSITION}

A. Isotopic

The feed material for the GPHS fuel pellets consists of $238 \mathrm{PuO}_{2}$ powder produced at SRP by adding oxalic acid to plutonium nitrate solution and then calcining the oxalate precipitate at 730 to $750^{\circ} \mathrm{C}$ to form plutonia. Based on a 1975 agreement between DOE, SRP, and LASL, the limits for the precipitations were set at $1.5 \pm 0.2 \mathrm{M}$ acid, $4-6 \mathrm{~g} / 7$ iter plutonium solution and $35 \pm 55^{\circ} \mathrm{C}$. The isotopic composition for a typical lot of $238 \mathrm{PuO}_{2}$ feed powder used at LASL is listed in Table I. The plutonium in this material is enriched at 80 at.\% $238 \mathrm{Pu}$, producing a thermal power density of $0.398 \mathrm{~W} / \mathrm{g}$ of plutonium.

In the future, production-grade pellets will be fabricated at SRP from $238 \mathrm{PuO}_{2}$ feed powder wherein the plutonium will be enriched at 83.5 at.\% $238 \mathrm{pu}$. The values listed in Table I will be slightly different for this material. Production of the more highly enriched feed powder was recently initiated at SRP. However, at this time, none of the new material has been received at LASL for characterization studies. Accordingly, the dies for all GPHS pellets made at LASL for the Design Phase impact tests have been charged at $152.44 \mathrm{~g}$. This charge will produce a thermal inventory of about 63.2 watts as pressed and 62.5 watts during mission 1 ife if the feed enriched at 83.5 at. $\%$ 238pu is used. The sizing of the pellet charge based on the more highly enriched feed ensures that the densities and microstructures for the pellets used in the LASL Design Phase 


\section{INTLRNAL CRACKS IN $\mathrm{PUO}_{2}$ CAUSED \\ BY SINTERING EFFECTS}

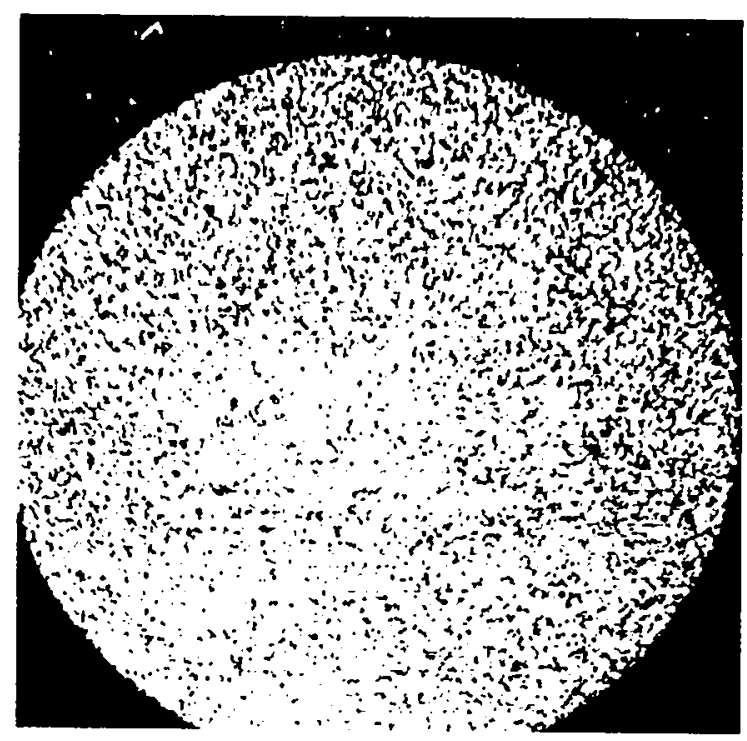

As Pressed - 36\% TD

$X ? O F$

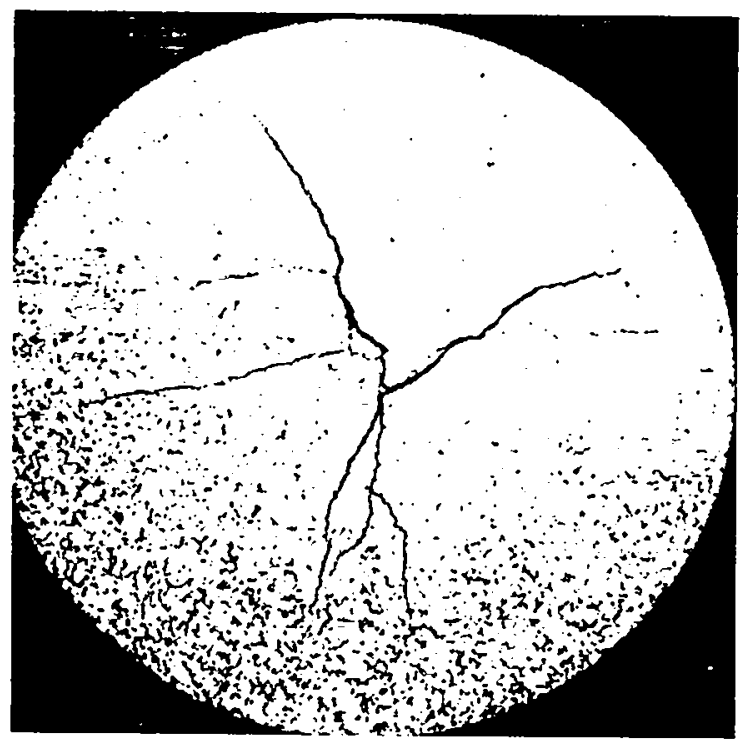

Sintered at $1350^{\circ} \mathrm{C}-87 \%$ TD

X10P

Fig. 2. Cross sections for developmental pellets made without GROG-type feed. 
DEVELOPMENTAL STUDIES PELLETS

EFFECTS OF RROS FEE!

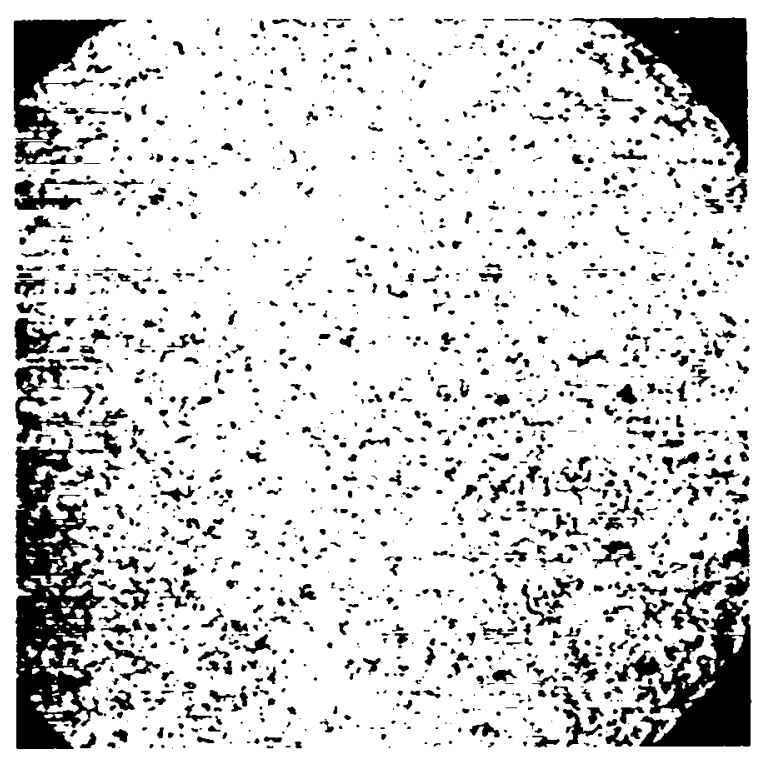

Sintered at $1350^{\circ} \mathrm{C}-85 \%$ TD $\mathrm{X10P}$

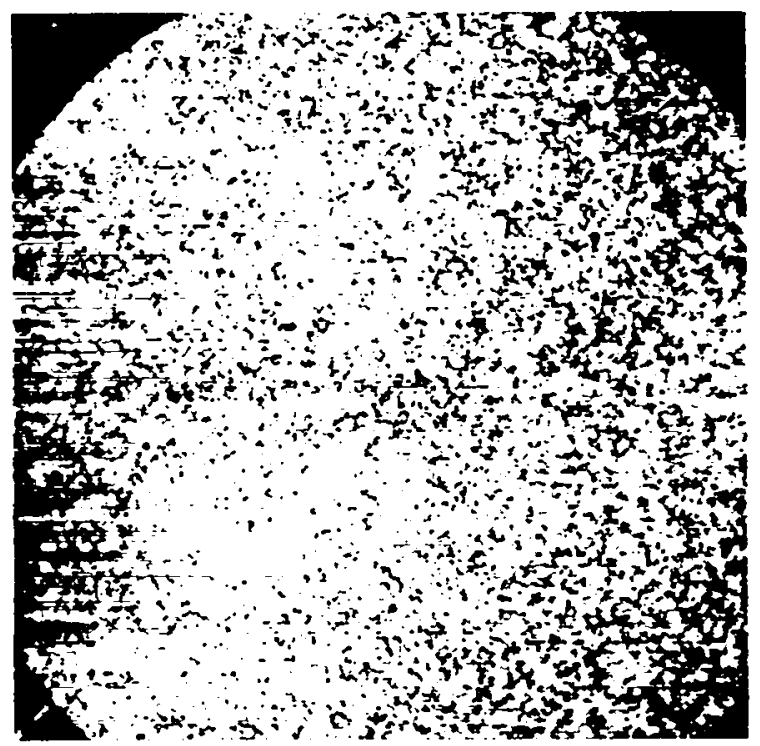

Sintered at $1600^{\circ} \mathrm{C}-85 \%$ TD $\mathrm{X}$ (10P

Fig. 3. Cross sections for developmental pellets made with GROG-type feed. 
GPHS

62.5- $!$ ! PELLET

GROG-TYPE FEED

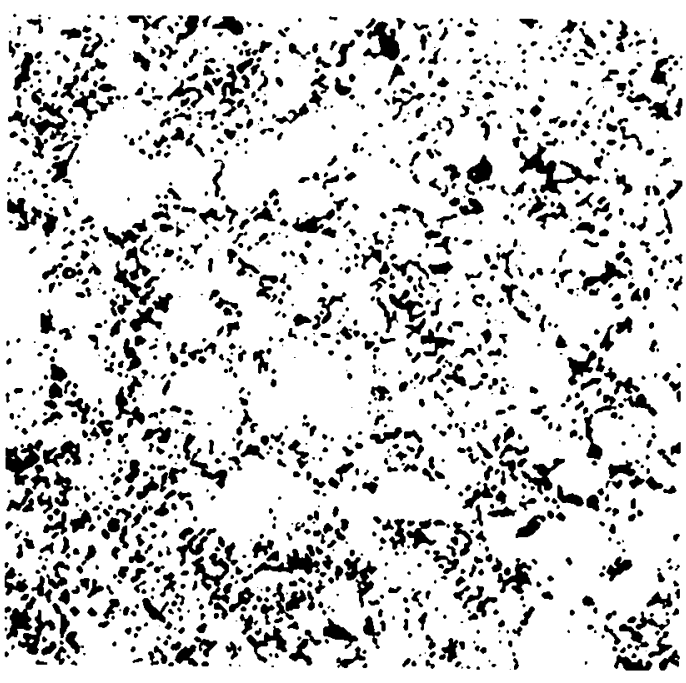

$100 \times P$

Core

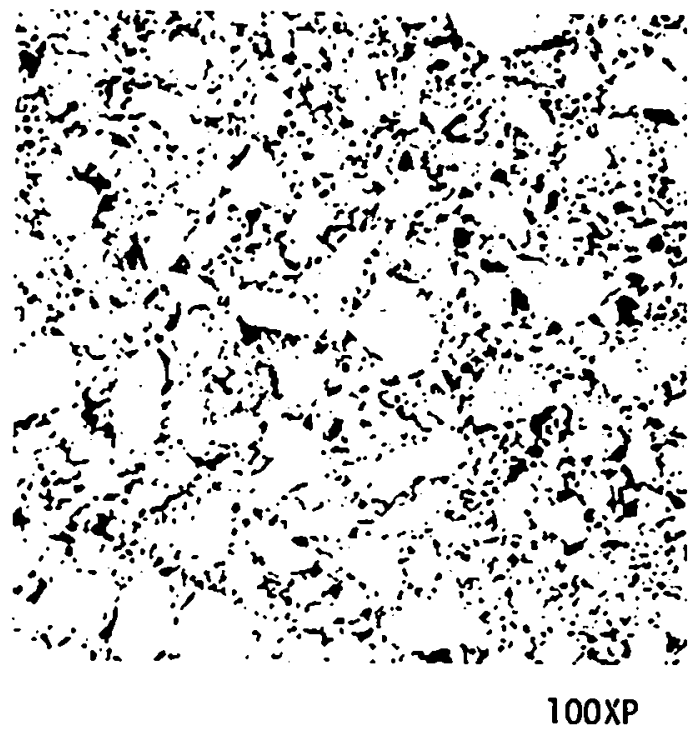

Edge

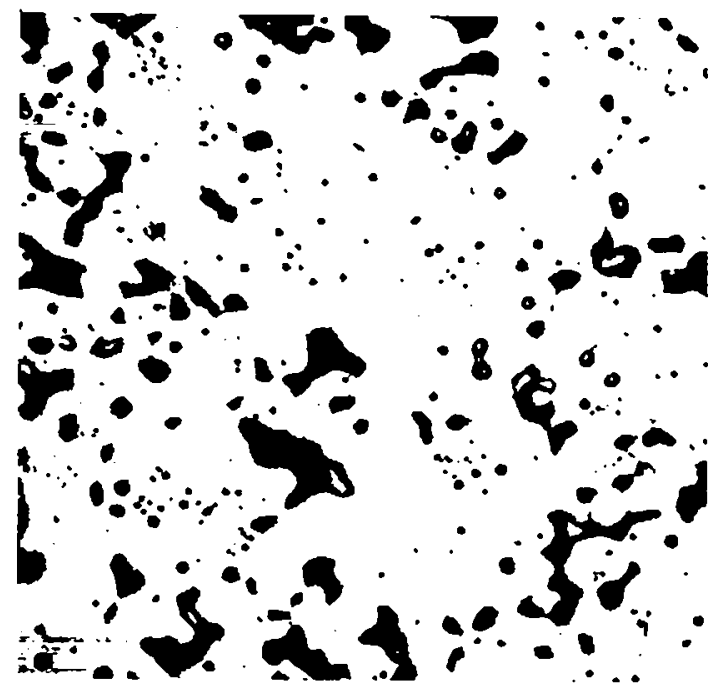

Sintered at $1527^{\circ} \mathrm{C}$

500XE

Fig. 4. Metallographic data for 62.5-W GPHS pellet. 
TABLE I

PLUTONIUM CONTENT FOR TYPICAL SRP ${ }^{238} \mathrm{PuO}_{2}$ FEED USED AT LASL

\begin{tabular}{|c|c|c|c|}
\hline Isotope & $\begin{array}{c}\text { Abundance } \\
\text { (wt\%) }\end{array}$ & $\begin{array}{l}\text { Half-Life } \\
\text { (yr) }\end{array}$ & $\begin{array}{c}\text { Radiation } \\
\text { Type }\end{array}$ \\
\hline $236 \mathrm{Pu}$ & 0.0001 & 2.8 & $\alpha^{a}$ \\
\hline $238 \mathrm{Pu}$ & 80.0 & $87.80 \pm 0.02$ & $\alpha^{b}$ \\
\hline $239 \mathrm{Pu}$ & 16.5 & $2.4 \times 10^{4}$ & $\alpha$ \\
\hline $240 \mathrm{Pu}$ & 2.5 & $6.6 \times 10^{3}$ & $\alpha$ \\
\hline${ }^{241} \mathrm{Pu}$ & 0.8 & 13.0 & $\beta$ \\
\hline $242 \mathrm{Pu}$ & 0.2 & $3.7 \times 10^{5}$ & $\alpha$ \\
\hline
\end{tabular}

aDaughter products $(212 \mathrm{~Pb}, 212 \mathrm{Bi}$, and $208 \mathrm{Tl})$ produce moderate gamma radiation.

bThe alpha decay of $238 \mathrm{Pu}$ produces $234 \mathrm{U}$ (525 ppm/ month).

TABLE II

ACTINIDE IMPURITY LEVELS

FOR TYPICAL LASL PELLET

$\begin{array}{cll}\text { Element } & & \begin{array}{c}\text { Abundance } \\ (\text { wt\% })\end{array} \\ \text { Th } & & 0.03 \\ U & & 0.64^{\mathrm{a}} \\ \mathrm{Np} & & 0.12 \\ \text { Am } & & 0.05\end{array}$

achanges with time due to alpha decay of $238 \mathrm{Pu}$. 
impact tests are representative of those that will occur for SRP production pellets if the LASL fabrication flowsheet is followed.

B. Actinide Content

The typical actinide content of a fuel pellet made with SRP feed material enriched at 80 at. $\% 238 \mathrm{Pu}$ is listed in Table II. Production pellets made with feed enriched at 83.5 at.\% $238 \mathrm{Pu}$ will contain slightly more ${ }^{234} \mathrm{U}$ which is produced by the alpha decay of $238 \mathrm{pu}$ at the rate of $525 \mathrm{ppm} / \mathrm{month}$. The actual $234 \mathrm{U}$ content for any given fuel pellet will, of course, depend on the age of the pellet and the initial isotopic composition of the feed material.

C. Impurity LeveTs

The specified impurity levels for the GPHS fuel are assumed to be the same as for the MHW fuel.6 These impurity levels, together with LASL spectrochemical data for several lots of as-received SRP feed powder, are listed in Table III. The analytical data listed in this table indicate that the impurity levels in the feed powder are generally lower than those specified for MHW fuel.

Most processed fuel forms contain fewer impurities than the feed powder because of the removal of light element impurities during hot pressing (in vacuum) and post-press sintering operations. The post-impact spectrochemical data for LASL sphere SPP-71 are 1isted in Table IV. This sphere, fabricated according to the LASL homogeneous MHW flowsheet, was encapsulated at MF and impacted at LASL.

Again, it should be noted that the spectrochemical data are for feed enriched at 80 at. $\%{ }^{238} \mathrm{Pu}$. None of the new feed enriched at 83.5 at. $\% 238 \mathrm{Pu}$ has been characterized at LASL.

\section{PROCESSING FLOWSHEET AND PROCEDURES}

A. General

All operations requiring the handling of unencapsulated $238 \mathrm{PuO}_{2}$ are performed in gloveboxes. These gloveboxes are constructed with stainless steellead-stainless steel sandwich-type walls and have highly polished interiors to facilitate cleaning. Glovebox windows are safety glass held in position by viton gaskets that are provided with stainless steel fire shields. The gloves consist of two layers of hypalon separated by a thin layer of lead. Neutron attenuation is provided by 4 inches of hydrogenous shielding located outside the glovebox. This shielding consists of Lucite panels over the glovebox windows and water-filled steel tanks el sewhere.

With this glovebox-shielding combination, we have been able to process 16 $\mathrm{kg}$ of ${ }^{238} \mathrm{PuO}_{2}$. including residues, while limiting personnel exposures to less than 1 REM per year.

All processing gloveboxes are provided with inert gas, argon or helium, atmospheres. This is accomblished by either a continuous inert gas pass through (< $10 \mathrm{ppm}$ oxygen) or a closed loop recirculating system (<1 ppm oxygen) using a Vacuum Atmospheres Company Mode1 M040 2HA Dri-train unit. GToveboxes are attached to one another via vacuum/inert-gas airlocks. Thus, if any glovebox is breached, the atmospheres of neighboring boxes are not affected.

For the purposes of description, the production of encapsulated GPHS pellets from raw SRP feed powder may be separated into 8 characterization and processing steps. These steps, each of which is described in detail below, are 
TABLE III

SPECTROCHEMICAL DATA SUMMARY

FOR ELEVEN SRP FEED LOTS

(ppm by weight)

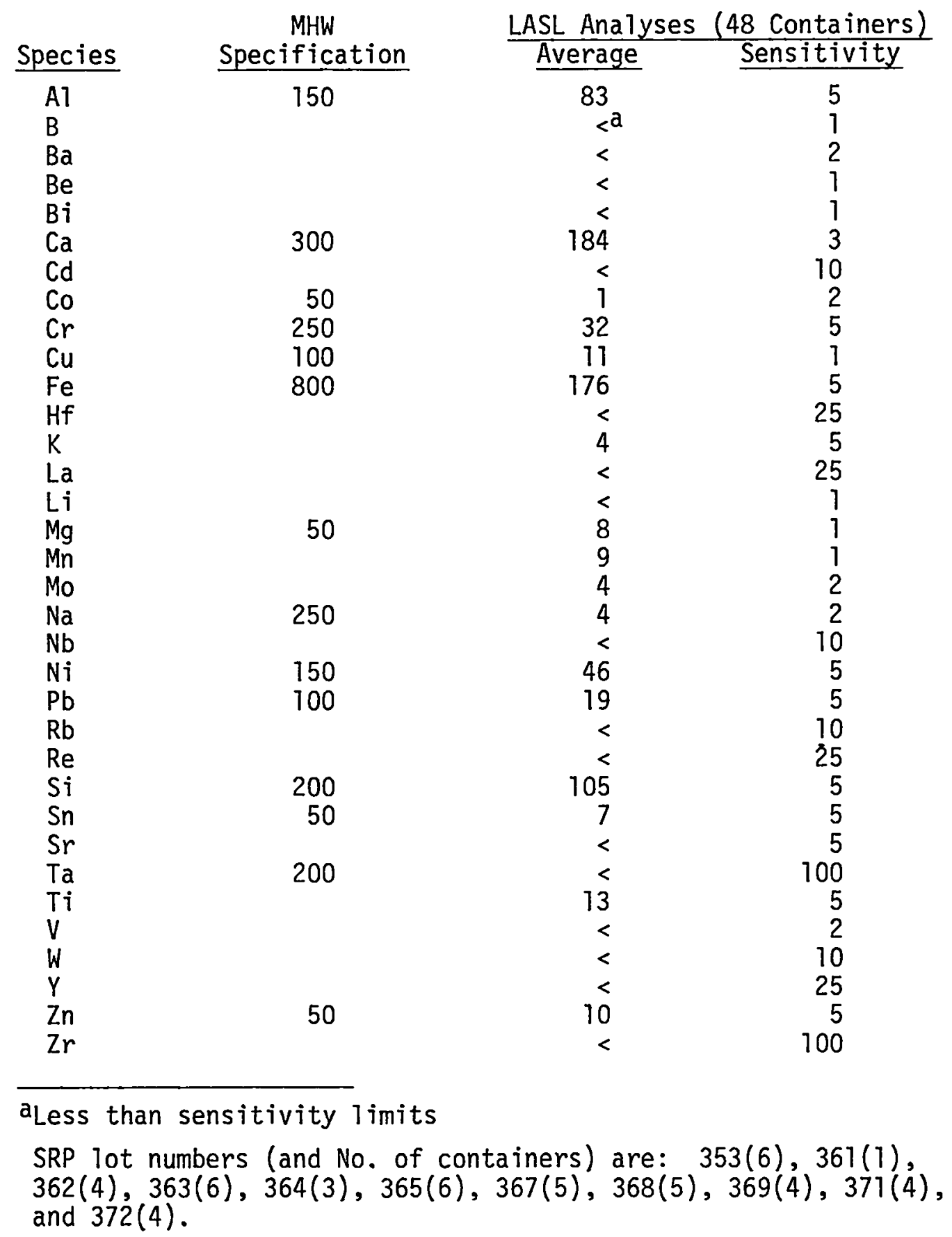


TABLE IV

SPECTROCHEMICAL DATA FOR LASL

SPHERE SPP-7I AFTER IMPACT

(MHFT-60-LB)

\begin{tabular}{|c|c|}
\hline Species & $\begin{array}{l}\text { ppm by } \\
\text { weight }\end{array}$ \\
\hline Al & 10 \\
\hline $\mathrm{Ca}$ & 10 \\
\hline $\mathrm{Cr}$ & $<\mathrm{a}$ \\
\hline $\mathrm{Cu}$ & 1 \\
\hline $\mathrm{Fe}$ & 55 \\
\hline $\mathrm{Mg}$ & 1 \\
\hline $\mathrm{Mn}$ & 1 \\
\hline Mo & 20 \\
\hline $\mathrm{Na}$ & 20 \\
\hline $\mathrm{Ni}$ & $<$ \\
\hline $\mathrm{Pb}$ & 10 \\
\hline $\mathrm{Si}$ & 20 \\
\hline Sn & $<$ \\
\hline $\mathrm{Ti}$ & 5 \\
\hline $\mathrm{Zn}$ & 15 \\
\hline $\mathrm{Zr}$ & $<$ \\
\hline
\end{tabular}


1. Calorimetry and Analyses of Incoming Feed

2. 0xygen-16 Exchange

3. Ball-Milling

4. Slugging and Screening

5. Granule Seasoning

6. Hot Pressing

7. Post-Press Sintering

8. Encapsulation

B. Calorimetry and Analyses of Incoming Feed

These are not processing steps per se. However, the feed must be characterized if pellets having the desired characteristics are to be made repeatedly. In addition, the calorimetric measurements enable accurate accounting for the plutonium. Fresh SRP feed is shipped to LASL in a double container assembly usually charged with about $220 \mathrm{~g}$ of plutonia. Details of the 5320 shipping container are shown on Drawing 26Y-79234C 1 presented in the appendix. A revised secondary container is being designed at SRP to meet new National Regulatory Commission (NRC) regulations. In the interim, the old shipping container is being used with the secondary cap welded shut prior to shipment.

1. Calorimetry. The isothermal calorimeter used was designed and built at LASL. The unit wi17 not be described in detail because the electronics are currentiy being upgraded. At the present time, the unit is capable of measuring samples with thermal inventories ranging from 0.1 to $190 \mathrm{~W}$ with a precision of $\pm 0.02 \mathrm{~W}$. The calorimeter may be calibrated electrically or with a standard sample consisting of $99.998 \%$-pure $238 \mathrm{Pu}$ electrorefined at LASL and measured calorimetrically at LASL and MF. The 5320 shipping container is placed in the water bath unopened and the thermal inventory is measured in watts. This value, divided by the factor $0.5688 \mathrm{~W} / \mathrm{g}$, yields the amount of ${ }^{238} \mathrm{Pu}$. After calorimetry, the 5320 shipping container is introduced to the glovebox 1 ine and the secondary container is sawed open and discarded. Care must be taken not to damage the primary container or glovebox gloves. The primary container is opened and the feed powder is transferred to a tared stainless steel pan and weighed. Care must be taken to prevent the metal gas-filled o-ring falling into the powder as the rapid temperature rise can cause the o-ring to expand and burst. Weighings are performed on Ainsworth GAMMA-III, Mod. 2 chain-o-matic balances made to LASL specifications. These balances have a capacity of $300 \mathrm{~g}$ with a sensitivity of $\pm 0.5 \mathrm{mg}$. The type-S weights used are certified by comparison to National Bureau of Standards (NBS) standard weights. The bulk weight of the feed powder is combined with the calorimeter value to determine the thermal inventory $(\mathrm{W} / \mathrm{g})$ for this material. At this point, a Shipper-Receiver difference is written if reguired for accountibility.

2. Analyses. Next, analytical samples are taken if desired. We generally take 4 samples to determine the (a) actinide content, (b) trace impurity levels, (c) neutron emission rate, and (d) particle size distribution. Typical actinide content and spectrochemical values for fresh SRP feed are 1 isted in Tables II and III, respectively. The neutron emission rate and particle size data are discussed below. Each $7-g$ analytical sample is weighed on a chain-0matic balance and transferred to a tantalum container. These containers are cleaned ultrasonically in ethanol and baked in vacuum at $200^{\circ} \mathrm{C}$ prior to introduction of the analytical sample. The containers are then welded shut and transferred to the analytical group. 


\section{Oxygen-16 Exchange}

The first processing step performed at LASL involves heating the asreceived feed powder in an 0xygen-16 environment to replace the ${ }^{170}$ and ${ }^{180}$ isotopes present in the feed with 160 . The feed powder produced at SRP has a neutron emission rate in excess of $17000 \mathrm{n} / \mathrm{s}-\mathrm{g} 238 \mathrm{Pu}$, primarily due to $(\alpha, n)$ reactions caused by the presence of 170 and 180 isotopes in the normal oxygen used in the SRP calcining operations.

The exchange is accomplished by heating a platinum boat, filled with the appropriate amount of feed powder, in a horizontal tube furnace in an atmosphere of flowing $\mathrm{Ar}$ saturated with $\mathrm{H}_{2}{ }^{160}$. We use $\mathrm{H}_{2}{ }^{16} \mathrm{O}$ rather than gaseous $16 \mathrm{O}_{2}$ because the $\mathrm{H}_{2}{ }^{16} 0$ is readily available at low cost as a byproduct of the production of $15 \mathrm{~N}_{2}$ by another LASL group. The feed material is exchanged for $24 \mathrm{~h}$ at $775^{\circ} \mathrm{C}$ and then heated for $\mathrm{I} \mathrm{h}$ at $1000^{\circ} \mathrm{C}$ to release stored helium. The furnaces are programmed for heating and cooling rates of $300^{\circ} \mathrm{C} / \mathrm{h}$. The $\mathrm{Ar}-\mathrm{H}_{2} 16 \mathrm{O}$ flow is maintained throughout the run and approximately $30 \mathrm{ml}$ of $\mathrm{H}_{2}{ }^{16} 0$ are used per $70 \mathrm{~g}$ of plutonia powder.

The results of experiments performed at LASL to determine the neutron emission rate as a function of exchange time are listed in Table $V$. These data indicate that the neutron emission rate specified for MHW fuel $(8000 \mathrm{n} / \mathrm{s}-\mathrm{g}$ $238 \mathrm{Pu}$ ) can be obtained by exchanging the plutonia for $6 \mathrm{~h}$ at $775^{\circ} \mathrm{C}$ followed by $l \mathrm{~h}$ at $1000^{\circ} \mathrm{C}$. The data also indicate the increase in exchange efficiency with time. In theory, the minimum possible emission rate is set by the spontaneous fission rate, $2880 \mathrm{n} / \mathrm{s}-\mathrm{g} 238 \mathrm{Pu}$. In practice, minimum emission rates near 4500 $\mathrm{n} / \mathrm{s}-\mathrm{g} 238 \mathrm{pu}$ are obtained by exchanging the material for $24 \mathrm{~h}$ at $775^{\circ} \mathrm{C}$ followed by $l \mathrm{~h}$ at $1000^{\circ} \mathrm{C}$. It is possible to increase the exchange rate by increasing the temperature, but this has deletorious effects on subsequent feed behavior. Neutron emission rates for several lots of SRP feed powder, both asreceived and after exchange at LASL, are listed in Table VI. Siight differences in emission rates for exchanged lots can be attributed to lot-to-lot variations in the content of 1 ight element impurities that can cause $(\alpha, n)$ reactions.

1. Equipment. Two models of furnaces are used, Astro Industries, Inc., Model 1000A and Centorr Associates, Inc., Mode1 10-4X16-G-0-17. Both furnace models are horizontally mounted and are provided with alumina core tubes mounted between the resistnace-heated graphite elements. While the Centorr furnaces have been adequate for the exchange reactions they have proved unsatisfactory for the granule seasoning and post-press sintering operations performed at higher temperatures. Two gas streams are introduced into the furnaces at one end, pass through the furnace and then exit to the glovebox exhaust. The core gas consists of Ar containing 6 vol\% $\mathrm{H}_{2}$. This is passed between the graphite heating elements and the alumina core to protect the heating elements should the core tube break. The reaction gas consists of Ar passed through a bubbler containing $\mathrm{H}_{2} 160$ and then through the aluminum core. Before these gases are introduced into the exchange furnace, they are purified by passing them through Lindberg Model 70 tube furnace containing titanium beds at $750^{\circ} \mathrm{C}$. Valves and flowmeters are used to regulate gas flows. Alumina baffles are placed at both ends of the alumina tubes to moderate the flow of the $\mathrm{Ar}-\mathrm{H}_{2} 160$ required. In addition, when the Astro furnaces are used in the high-temperature post-pressing sintering operations, the baffles prevent cold gases from coming in contact with the hot pellets and. thus, producing thermal shock to the pellet.

The platinum boats used to contain the plutonia powder are made by deep drawing (no welded seams) to facilitate cleaning. Two sizes are used. The boats for the Astro furnaces are normally loaded with 40 to $70 \mathrm{~g}$ plutonia, those 
TABLE V

NEUTRON EMISSION RATE AS A

FUNCTION OF EXCHANGE TIME

\begin{tabular}{c}
$\begin{array}{c}\text { Exchange Time } \\
\text { (h) }\end{array}$ \\
\hline As Receiveda \\
$6^{\text {b }}$ \\
12 \\
18 \\
24
\end{tabular}

Emission Rate

(n/s-g $238 \mathrm{Pu})$

17206

8015

6074

4676

adata is for SRP lot 182, run 108816.

bexchange runs were 6 to $24 \mathrm{~h}$ at $775^{\circ} \mathrm{C}$ plus $1 \mathrm{~h}$ at $1000^{\circ} \mathrm{C}$. 
TABLE VI

NEUTRON EMISSION DATA

FOR SRP FEED LOTS

\begin{tabular}{|c|c|c|c|}
\hline \multirow[b]{2}{*}{$\begin{array}{c}\text { SRP } \\
\text { Lot No. }\end{array}$} & \multirow{2}{*}{$\begin{array}{l}\text { No. Runs } \\
\text { Processed } \\
\text { at LASL }\end{array}$} & \multicolumn{2}{|c|}{$\begin{array}{c}\text { Neutron Emission Rate } \\
(\mathrm{n} / \mathrm{s}-\mathrm{g} 238 \mathrm{Pu})\end{array}$} \\
\hline & & $\begin{array}{c}\text { As } \\
\text { Received }\end{array}$ & Exchanged \\
\hline 353 & 6 & 17721 & 4615 \\
\hline 361 & 1 & 17350 & 4641 \\
\hline 362 & 4 & 17787 & 4879 \\
\hline 363 & 6 & 17682 & 4405 \\
\hline 364 & 3 & 17721 & 4487 \\
\hline 365 & 6 & 17661 & 4364 \\
\hline 367 & 5 & 17683 & 4557 \\
\hline 368 & 5 & 17714 & 4423 \\
\hline 369 & 4 & 18005 & 5108 \\
\hline 371 & 4 & 18046 & 4859 \\
\hline \multirow[t]{2}{*}{372} & 4 & 17921 & 4899 \\
\hline & & $\begin{array}{l}17754 \\
\pm \quad 191\end{array}$ & $\begin{array}{r}4658 \\
\pm 244\end{array}$ \\
\hline
\end{tabular}


for the Centorr furnaces are normally loaded with 80 to $140 \mathrm{~g}$. In either case, the powder bed depth at the center of the boat is about $12.7 \mathrm{~mm}$. The $102-\mathrm{mm}-$ long boats are positioned in the alumina tube at the center of the 152-mm-long furnace hot zone. Exchange cycles are predetermined by means of Research Inc., Model FGE 5110 Data Track programmers and Honeywe11 Model 117LPF Dial-a-Trol controllers. Two Pt-Pt 10Rh thermocouples, certified by comparison to NBS standard couples are used. One couple is used to measure the temperature of the feed and the signal is displayed on a stripchart recorder. The signal from the second couple is fed to the controller.

2. Procedure. The step-by-step procedure for the exchange reaction is 7 isted below. This procedure is taken from the LASL standard operating procedures (SOPS) as are the procedures listed below for the other processing steps. taken.

a. Record lot ID and weight after initial analytical samples have been

b. Load 40 to $70 \mathrm{~g}$ plutonia into a clean and tared platinum boat if an Astro furnace is to be used. Load 80 to $140 \mathrm{~g}$ plutonia into a larger boat if a Centorr furnace is to be used. The number of boats and the charge per boat should be selected so as to have approximately the same weight of powder in each boat.

c. Position boat and thermocouples in furnace. Seal furnace.

d. Check that correct chart is on Data Track drum.

e. Check that adequate $\mathrm{Ar}$ and $\mathrm{H}_{2}{ }^{16} \mathrm{O}$ are avajlable. Record $\mathrm{H}_{2}{ }^{160}$ level.

f. Check that recorder has adequate chart paper.

g. Record furnace number and run conditions.

$h$. Begin gas flow and programmed run cycle.

i. Repeat steps $b$ through $h$ till all material is loaded.

j. At end of programmed run cycle, remove boat from one furnace. Weigh

boat and record exchanged weight. Record amount of $\mathrm{H}_{2}{ }^{160}$ used.

$k$. Place record chart for run in lot folder.

1. Weigh and record $1 \mathrm{~g}$ analytical sample if neutron emission rate is to be determined.

$m$. Repeat steps $j$ and $k$ for other boats.

$n$. Transfer exchanged plutonia to ball mills. If mills are not available, store material in clean, tared stainless steel cans, approximately $100 \mathrm{~g}$ per can.

o. From initial and exchanged weights determine processing losses, if any. Record same.

D. Ball-Milling

The second LASL processing step involves milling the feed powder to produce the desired particle size and powder morphology. This is, to some extent, a normalizing step to eliminate differences in surface activities from one lot of feed powder to the next. Particle size data for several lots of SRP feed powder, both as-received and after ball-milling at LASL, are listed in Table VII. The as-received powder consists of two types of particles and has a mass-median diameter of about $2.7 \mu \mathrm{m}$. One type of particle is rosette-shaped, the other is lath-shaped. The lath-shaped particles have an extremely high surface activity and cause the material to shrink excessively when sintered. Milling the powder converts most of the lath-shaped particles to the less reactive rosette-shaped ones. The results of developmental studies performed at LASL indicate that the reactivity of the feed will be adequately adjusted if the powder is milled to produce a mass-median diameter of about $0.6 \mu \mathrm{m}$. This requires $40 \mathrm{~h}$ in the LASL bal1-mill. 
PARTICLE SIZE DATA FOR SRP FEED LOTS

\begin{tabular}{|c|c|c|c|}
\hline \multirow[b]{2}{*}{$\begin{array}{c}\text { SRP } \\
\text { Lot No. }\end{array}$} & \multirow{2}{*}{$\begin{array}{l}\text { No. Runs } \\
\text { Processed } \\
\text { at LASL } \\
\end{array}$} & \multicolumn{2}{|c|}{$\begin{array}{c}\text { Mass-Median Diameter } \\
(\mu \mathrm{m})\end{array}$} \\
\hline & & $\begin{array}{c}\text { As } \\
\text { Received }\end{array}$ & Ball-Milled \\
\hline 353 & 6 & 3.2 & 0.66 \\
\hline 362 & 4 & 2.3 & 0.59 \\
\hline 363 & 6 & 2.5 & 0.58 \\
\hline 364 & 3 & 2.8 & 0.47 \\
\hline 365 & 6 & 3.0 & 0.64 \\
\hline 367 & 5 & 2.6 & 0.69 \\
\hline & & $2.7 \pm 0.3$ & $0.67 \pm 0.08$ \\
\hline
\end{tabular}


The LASL mills operate at $27 \mathrm{rpm}$ and approximately $2 \mathrm{ppm}$ of iron are introduced to the feed powder per hour of milling. Slight changes in precipitation conditions at SRP can effect a change in the ratio of lath-shaped to rosetteshaped particles. If the material is, or is suspected of being, too reactive, we simply mill it longer. We have milled feed powder for more than $100 \mathrm{~h}$ with no noticeable deletorious effects, i.e., one can't overmill the powder. Too short milling times, however, definitely result in pellets that shrink excessively when sintered. It is conceivable that the milling time could be shortened if the rolling rates were increased. However, this has not been proven conclusively and faster rolling rates could result in a significant increase in the iron content.

1. Equipment. Each ball-milling assembly consists basically of a set of rollers and stainless steel jars. Each jar contains fifty-five 15.9-mm-diam hardened steel $(440 \mathrm{C})$ balls. Details for the roller assembly are shown on drawings 26Y-79394 DI and 26Y-79394 C2. Details for the jar are shown on drawing $26 \mathrm{Y}-74491 \mathrm{DI}$. Each of these drawings is presented in the appendix. The rollers are powered by a Bodine Model NSH-33R motor rated at $1 / 20 \mathrm{hp}$ at $43 \mathrm{rpm}$. The rolling rate is set with a Minarik Electric Company Model W33 speed control. Particle size analyses are performed with a Micromeritics Instrument Corporation Sedigraph Model $5000 \mathrm{~GB}$.

2. Procedure.

a. Record lot ID and weight of the powder as transferred after the exchange step.

b. Check that stainless steel jars and balls are clean and that each jar contains the proper number of balls.

c. Weigh the charge for a single jar, 50 to $70 \mathrm{~g}$ of plutonia.

d. Load jar using stainless steel funnel and close and seal jar, tightening bolts evenly.

e. Repeat steps $c$ and $d$ for other jars until all material is loaded. The number of jars and the charge per jar should be selected so as to have approximately the same weight of powder per jar.

$f$. Check that jar lids are tight, place jars on rollers, set timer and begin milling. Record time and rpm.

g. After milling is completed, empty contents of one jar onto a clean No. 8 or 10 stainless steel screen positioned above a clean, tared stainless steel pan. Use a stainless steel brush to clean the balls, passing the feed through the screen to the pan below. Replace balls in jar and seal lid.

$h$. Weigh milled powder and record weight.

$i$ Weigh and record a $1 \mathrm{~g}$ analytical sample if the particle size is to be measured. If insufficient milling has occurred, reload the emptied jar and mill all jars longer.

j. If particle size data is satisfactory, or is not obtained, repeat steps $g$ and $h$ for the other jars.

k. Load the milled powder into clean stainless steel containers, approximately $100 \mathrm{~g}$ plutonia per container, for storage or transfer the slugging and screening area.

1. From the initial and milled weights determine the processing losses, if any. Record same.

E. Slugging and Screening

The slugging and screening operations are performed to convert the ballmilled powder to granules of the size desired for hot pressing. The plutonia 
powder is divided into an equal number of approximately $25 \mathrm{~g}$ charges, depending on feed lot size. Each charge is cold pressed at $400 \mathrm{MPa}$ to form a green pellet at $60 \%$ TD. The pellets are then broken and screened to size and the < 125-um fraction is collected and thermally seasoned.

1. Equipment. The cold pressing is performed with a Carver Mode] C laboratory press that can be operated manually or can be hydraulically plumbed for remote operation. The cold pressing die is shown on drawing $26 \mathrm{Y}-7487201$ presented in the appendix. The drawing calls for Ferrotic $C$ material. However, we have successfully used dies made from hardened tool steel. These dies have been approved by the LASL Die Safety Committee for use to $1.1 \mathrm{GPa}$. The die punches are lubricated with molybdenum disulfide and no binder is added to the plutonia powder. All screens, pans, rollers, funnels, forceps, and brushes used in these operations are stainless steel.

2. Procedure.

a. Record lot ID and bulk weight as transferred after ball-milling.

b. Clean and polish die assembly with clean cheesecloth.

c. Lubricate punches sparingly with molybdenum disulfide taking care

that no lubricant gets on punch faces.

d. Position bottom punch in die. Load appropriate amount of feed powder using funnel then position top punch.

e. Place die assembly on bottom press platen and slowly raise assembly till top punch touches and is square with top platen.

f. Apply force of $33.8 \mathrm{kN}$, hold for $1 \mathrm{~min}$ and release.

g. Apply force of $67.6 \mathrm{kN}$, hold for $1 \mathrm{~min}$ and release.

h. Apply force of $101.4 \mathrm{kN}$, hold for $\mathrm{I}$ min and release.

$i$. When pressing cycle is completed, remove and invert die assembly.

Remove top punch and position spacer. Reposition die assembly and eject pellet, using minimum force.

j. Remove pellet with forceps and place on 600-um screen positioned above a $125-\mu \mathrm{m}$ screen that in turn is positioned above a tared pan.

k. Use roller to gently break up pellet. Use roller and brush to pass al1 material through the 600-um screen and collect granules on 125-um screen.

1. Use roller to pass material through 125-um screen to pan below. Use brush for residual tailings only.

m. If there are any granules $>125-\mu \mathrm{m}$, weigh and transfer them to a residue container.

n. Weigh tared pan to determine weight of $<125-\mu m$ granules. Record weight.

o. Repeat steps b through $n$ until all material is slugged and screened.

p. From initial weight and weight of slugged and screened granules, determine processing losses, if any. Record same.

F. Granule Seasoning

This is the most important pre-press processing step. After the $<125-\mu m$ granules are made they are thermaliy seasoned to form the reactive and nonreactive components of the GROG-feed mixture. The majority of the green granules, $60 \mathrm{wt} \%$, are seasoned for $6 \mathrm{~h}$ at $1100^{\circ} \mathrm{C}$ in flowing $\mathrm{Ar}-\mathrm{H}_{2}{ }^{16} \mathrm{O}$. The remaining granules, $40 \mathrm{wt} \%$, are seasoned for $6 \mathrm{~h}$ at $1600^{\circ} \mathrm{C}$. Heating and cooling rates for both seasoning operations are $300^{\circ} \mathrm{C} / \mathrm{h}$. Seasoning the granules in $\mathrm{Ar}-\mathrm{H}_{2}{ }^{16} \mathrm{O}$ prevents the back exchange of the $\mathrm{Pu}^{16} \mathrm{O}_{2}$ and, in addition, frequently leads to a further reduction (5 to $10 \%$ ) in the neutron emission rate. 
The most important parameter in processing the SRP feed prior to hot pressing is the temperature at which the reactive component of the GROG mixture is seasoned. If the temperature is too low, the granules will be too reactive, leading to excessive shrinkage and crack formation when the pellet is post-press sintered. If the temperature is too high, the granules will not be reactive enough to form around the nonreactive high-fired granules so as to produce a homogeneous microstructure. Thus, it is imperative that the temperature profiles be determined accurately for the furnaces to be used and that temperature control and measurement systems be in good working order. We routinely control the temperature at the boat for the reactive component granules to $1100 \pm 5^{\circ} \mathrm{C}$. If the granule seasoning temperatures are correct, the granules seasoned at $1100^{\circ} \mathrm{C}$ will be greenish-yellow to light brown and the granules seasoned at $1600^{\circ} \mathrm{C}$ will be dark gray to black..

After the granules have been seasoned, they are screened to break up any agglomerates that might have formed. They are then weighed and stored in stainless steel containers until used for hot pressing. Note that the granules seasoned at $1100^{\circ} \mathrm{C}$ and $1600^{\circ} \mathrm{C}$ are stored separately. The maximum amount stored in any container is about $150 \mathrm{~g}$. We have stored seasoned granules for as long as three months prior to hot pressing with no deletorious effects.

1. Equipment. The furnaces, programmers, controllers, thermocouples, and platinum boats used for the granule seasoning operations are the same as those used for the oxygen-16 exchange reaction. Heat and cooling rates and $\mathrm{Ar}-\mathrm{H}_{2} 160$ flow rates are also the same as those for the oxygen-16 exchange step. Note that only the Astro furnaces are used for the $1600^{\circ} \mathrm{C}$ seasoning operations.

2. Procedure.

a. Record lot ID and granule weight as transferred after slugging and screening.

b. Load 40 to $70 \mathrm{~g}$ of granules into a clean and tared platinum boat if an Astro furnace is to be used. Load 80 to $140 \mathrm{~g}$ into a larger boat if a Centorr furnace is to be used.

c. Position boat and thermocouples in furnace. Seal furnace.

d. Check that correct chart for $1100^{\circ} \mathrm{C}$ seasoning run is on Data Track drum.

e. Check that adequate $\mathrm{Ar}$ and $\mathrm{H}_{2}{ }^{16} \mathrm{O}$ are available. Record $\mathrm{H}_{2}{ }^{16} 0$ level.

f. Check that recorder has adequate chart paper.

g. Record furnace number and run conditions.

h. Begin gas flow and programmed run cycle.

$i$. Repeat steps $b$ through $h$ till all material to be seasoned at $1100^{\circ} \mathrm{C}$ has been loaded.

$j$. Repeat steps b through $i$ for material to be seasoned at $1600^{\circ} \mathrm{C}$. Note that different programmer chart is used and only the Astro furnaces are used for the $1600^{\circ} \mathrm{C}$ seasoning runs.

$k$. At end of programmed run cycle, shut off gas flow and remove boat from furnace. Weigh boat and record seasoned granule weight. Record amount of $\mathrm{H}_{2} 160$ used.

1. Repeat step $k$ for all boats. Place recorder charts in lot folder.

m. Combine all granules seasoned at $1100^{\circ} \mathrm{C}$ and pass them through a 70mesh $(208-\mu \mathrm{m})$ screen. Weigh and store granules in labelled stainless stee? container. Do not store more than about $150 \mathrm{~g}$ of granules in a single container. $\mathrm{n}$. Combine the granules seasoned at $1600^{\circ} \mathrm{C}$ and pass them through a 30 mesh $(600-\mu \mathrm{m})$ screen and then through a 70-mesh (208- $\mu \mathrm{m})$ screen. Weigh and store granules in a labelled stainless steel container. 
o. From the initial and seasoned weights, determine processing losses, if any. Record same.

G. Die Preparation and Loading

The GROG-type feed used to fabricate the GPHS fuel pellets is obtained by mixing the proper ratio of $<125-\mu \mathrm{m}$ granules seasoned at $1100^{\circ} \mathrm{C}(60 \mathrm{wt} \%)$ and $1600^{\circ} \mathrm{C}(40 \mathrm{wt} \%)$. The mixing is accomplished by putting the granules into a ball-mill jar and rolling it for 15 to $30 \mathrm{~min}$ at $27 \mathrm{rpm}$. No balls are used. The jar is charged with $153.44 \mathrm{~g}$ of granules. After the rolling is completed, the graphite hot pressing die is charged with $152.44 \mathrm{~g}$ of the granule mix.

The die assembly consists of a cylindrical insert, susceptor, locking pin, 2 punches and 2 endcaps. The pellet is formed in a hole bored through the insert and centered on the cylindrical axis. The susceptor is sized to the insert and the induction heating coil so as to maximize heating efficiency. The susceptor is provided with 7 blackbody holes for temperature measurement with an optical pyrometer. The insert and susceptor are positioned relative to one another by means of a locking pin. Two punches are introduced into the insert, one from each end. The travel of the punches during pressing is determined by the depths of the endcaps. The LASL die assembly has been designed to allow 2 pressings per insert. This is accomplished by employing endcaps with different depths so that the pellet is formed above or below the center of the insert bore. After the first pellet is pressed, new punches are employed and the endcaps are reversed for the second pressing. This ensures that the second pellet is formed in an unused region of the insert.

1. Equipment. The ball-mill jar used to mix the GROG-type feed granules is shown on drawing $26 \mathrm{Y}-79204 \mathrm{DT}$. The roller assembly is shown on drawings $26 \mathrm{Y}-$ 79673 D1 and 26 Y -79673 D2. A11 3 drawings are presented in the appendix. Note that no balls are employed during mixing. The motor and speed controller used for the roller assembly are of the same type as those used for ball-milling the feed powder.

The die assembly is shown on drawings $26 \mathrm{Y}-74791 \mathrm{Cl}$ and $26 \mathrm{Y}-79750 \mathrm{Dl}$ presented in the appendix. All die parts are machined from AXM-grade graphite produced by POCO Graphite, Inc. This material has consistentiy proved to be free of flaws and sufficiently pure to preclude significant degassing. Use of this die assembly will produce a hotpressed pellet with a centerline diameter of $27.78 \mathrm{~mm}$ and a centerline length of $27.88 \mathrm{~mm}$. Individual pellet dimensions will vary slightly depending on the tolerances obtained in machining the die and the reactivity of the plutonia feed granules. The LASL shops routinely produce dies machined to tolerances of 0.005 to $0.012 \mathrm{~mm}$.

2. Procedure.

a. Weigh $92.064 \mathrm{~g}$ of $<125-\mu \mathrm{m}$ granules seasoned at $1100^{\circ} \mathrm{C}$. Place these in the mixing-mill jar.

b. Weigh $61.376 \mathrm{~g}$ of $<125-\mu \mathrm{m}$ granules seasoned at $1600^{\circ} \mathrm{C}$. Place these in the same jar.

c. Record lot IDs and granule charges placed in jar.

d. Secure ball-mill jar lid. Place jar on roller assembly and roll for 15 to $30 \mathrm{~min}$ at $27 \mathrm{rpm}$.

e. While the GROG-type feed material is being mixed, select the insert and punches to be used.

f. Visualiy inspect the insert and punches. Measure the punch dimensions with a micrometer and record the dimensions. Do not use punches with dimensions that are outside the tolerances listed on drawing $26 \mathrm{Y}-79750 \mathrm{DI}$. 
g. Clean the insert and punches with pure ethanol using lint-free cheesecloth.

$h$. Wrap the insert and punches with aluminum foil to keep them clean and introduce them into the glovebox line.

$i$. For the first pressing with a new insert, introduce the bottom punch and position the long endcap, detail 2 on drawing $26 \mathrm{Y}-79750 \mathrm{DI}$, at the base of the insert.

j. After the GROG-type feed is mixed, weigh out a $152.44 \mathrm{~g}$ charge. The residual tailing will be $1 \mathrm{~g}$, less the amount adhering to the walls of the mixing jar. Transfer the tailing to a residue container. Record the tailing and charge weights.

$k$. Charge the die using a stainless steel funnel taking care that materia] is introduced into pellet cavity area without coating the insert bore.

1. Introduce the top punch and introduce the insert into the susceptor and engage lock pin. Position the short endcap, detail 1 on drawing 26Y-79750 DI, atop the insert and susceptor.

$m$. For the second pressing with an insert, repeat steps a through 1 except that only the punches need to be cleaned and the positions of the 2 endcaps are reversed.

H. Hot Pressing

The GPHS pellets are pressed one at a time in the LASL hot press assembly consisting of a hydraulic system, a vacuum system and an induction-heating system consisting of a work coil powered by a motor generator. The hydraulic system powers the 2 main pressing servorams and 3 actuators. The servorams are mounted vertically and extend into the vacuum chamber containing the work coil. The actuators are used to raise and lower the vacuum can so that the die assembly may be introduced and removed. The die assembly is separated from the servorams by graphite spacers so that, during pressing, the die assembly is centered in the work coil.

After the die is positioned, the system is evacuated by means of a diffusion pump. Typically we load the press in the afternoon, evacuate overnight and press the next morning. The overnight evacuation results in a vacuum chamber pressure of 6.7 to $13 \mu \mathrm{Pa}$.

After the chamber has been evacuated, the servorams, provided with watercooled load cells, are positioned so that the blackbody holes in the susceptor are centered on the slot in the workcoil. A slight preload, $517 \mathrm{kPa}$, is provided. The timer is then started and the motorgenerator is brought on to $67.5 \%$ full power. The temperature is monitored with an optical pyrometer. When the temperature reaches $1300^{\circ} \mathrm{C}$, about 4.1 min into the run, the programmed load cycle is initiated. When the susceptor temperature reaches $1530^{\circ} \mathrm{C}$, about 6 min into the run, the motor generator is reduced to $50 \%$ power for the remainder of the run. The full programmed load, $11.8 \mathrm{kN}$ corresponding to $19.5 \mathrm{MPa}$ for GPHS pellets, is attained in 8 to 9 min from the initiation of the load cycle.: The die is held at $1530^{\circ} \mathrm{C}$ under full load for $15 \mathrm{~min}$, although punch closure is typicaliy attained in less than $10 \mathrm{~min}$. At the end of the pressing cycle, the motor generator is turned off and the load is removed from the die assembiy. The chamber is allowed to cool for about $1 \mathrm{~h}$ and then the vacuum system is valved off and dry argon is introduced into the chamber to facilitate cooling. After a suitable cooling period, the vacuum can is raised and the die assembly is removed. Typically, we press in the morning and remove the die in the afternoon. 
The hot press system is complex and a number of problems were encountered during initial use. The water cooling for the load cells, work coil and vacuum can was found to be inadequate. The load-cell heating was solved by adding a single pyrolytic graphite spacer to the stacks above and below the die assembly. The overheating of the work coil and vacuum can was solved by the addition of a booster pump to the limited-volume cooling water system. In addition, heating rates for the die assembly were too slow. This was solved by wrapping a layer of 6.4-mm-thick graphite felt around the susceptor and holding it in place with graphite screws.

After these modifications were made, the system was used, without further change, to make 22 GPHS pellets according to the flowsheet described in this report.

1. Equipment. The LASL hot press system is similar to and has the same capabilities as the production unit at SRP except that the LASL press is loaded, operated, and unloaded manually. The Materials Test Systems 2-cycle press unit consists of 2 servoram actuators in a closed-cycle test loop and 3 safetyinterlocked actuators that are used to raise, lower, and clamp the stainless steel vacuum chamber into position. The controls and hydraulic manifolding are designed so that both actuator loops can be operated simultaneously or independently. Each of the main servorams is provided with a water-cooled load cell of the type shown on drawing 26Y-79355 D1, presented in the appendix. Either servoram may be used as the main control ram. The pressing cycle is determined by use of a Data Trak programmer and the integrated signal from the load cel1 located in the master servoram. Three Hewlett-Packard Model 7100B 2-pen recorders are used to display the displacement or stroke, ram velocity and loaded cell output for both servorams. The hydraulic fluid used is Fyrquel phosphate ester, military specification No. MIL-H-83282, and the system, as plumbed, is capable of producing a maximum load force of $16.3 \mathrm{kN}$.

The heating system consists of a 100 kVA motor generator and associated controls. Water-cooled leads carry the rf current from the capacitor bank to the work coil. Temperatures are measured by sighting with a Micro Optical pyrometer through an optical quartz window into 1 of 7 blackbody holes drilled into the susceptor. Water cooling for the load cells, double-wall vacuum chamber, capacitor bank, rf leads and work coil is provided with a limited-volume positive-pressure water system with a capacity of $30 \mathrm{l}$.

The vacuum system consists of a Varian 102-mm-diam Model M4 diffusion pump backed by a Welch Model 1397B mechanical pump. Convoil No. 20 oil is used in both pumps. Suitable manifolding is provided so that the vacuum chamber may be evacuated to $6.7 \mathrm{~Pa}$ prior to opening the gate valve to the diffusion pump. Chamber pressure is measured by thermocouple gauges and a Granville-Phillips Mode] 270 ion guage controller connected to a Bayard-Alpert guage connected to a high vacuum flange by means of a kovar seal.

2. Procedure. Assume that prior to the pressing cycle the hydraulic system and the motor generator are off and that the chamber is evacuated.

a. Turn off ion guage and close gate valve between vacuum chamber and diffusion pump. Open valves to dry argon sypply and bring vacuum chamber to ambient glovebox pressure.

b. Turn Master Control power ON. Reset interlocks if necessary. Turn on channels 1 and 2 and set at HIGH RANGE.

c. Check that servorams are in fully retracted position.

d. Switch by-pass clamp interlock to BY-PASS position.

e. Turn Lift-Clamp switch to LIFT and raise vacuum chamber. 
f. Place die assembly onto the bottom load column. Check that correct number of graphite spacers are used, above and below the die assembly.

g. Align blackbody holes in susceptor with slot in work coil.

$h$. Check that o-rings and sealing surfaces are clean. Turn Lift-Clamp switch to CLAMP and lower vacuum chamber.

i. When CLAMP signal light is on, open the by-pass valve to the mechanical pump.

j. When chamber is evacuated to $6.7 \mathrm{~Pa}$, open the gate valve to the diffusion pump and close the by-pass valve to the mechanical pump. Wait 5 min, then turn on ion guage. The chamber pressure should be about $6.7 \mathrm{mPa}$.

k. Turn hydrautic system OFF if pressing is to be performed next morning. If pressing is to be performed immediately, go to step 1 .

1. Turn Master Control power to $0 \mathrm{~N}$. Reset interlocks if necessary. Turn on channels 1 and 2 and set at HIGH RANGE. Be sure that the Set Point Control indicates a negative signal (servo rams retracting).

m. Turn by-pass clamp interlock to PRESS position. Let press electronics warm up for 30 min.

$n$. Zero out the load signal on both Model 442 controllers. Increase Set Point Control to about zero and slowly move servorams in till system is in LOAD CONTROL.

o. Turn on cooling water booster pump and open valve to the system.

p. Turn on motor generator and allow it to warm up for 5 min.

q. Check that DATA TRACK has correct chart. Advance DATA TRACK to initiation of programmed run cycle. Switch Master Control Panel to PROGRAM AND RECORD on channel 2. Check all recorders for set points and ink flow.

$r$. Start timer and bring motor generator to $67.5 \%$ full power.

$\mathrm{s}$. Measure susceptor temperature at 10 to $15 \mathrm{~s}$ intervals with the optical pyrometer.

t. When temperature reaches $1300^{\circ} \mathrm{C}$ (true) initiate programmed load cycle by switching DATA TRACK to RUN.

u. Monitor and record temperature and load throughout the run.

v. When temperature reaches $1530^{\circ} \mathrm{C}$ (true) reduce motor generator to $50 \%$ full power for remainder of run.

w. Note when system is at programmed load. This will occur about 4 min after initiation of load cycle. Maintain programmed load at $1530^{\circ} \mathrm{C}$ temperature for 15 min.

$x$. Turn off motor generator and rotate DATA TRACK to down slope to releave load. When servorams are fully retracted, introduce a negative signal to the Set Point Control and turn off the hydraulic system.

$y$. When vacuum chamber has cooled for $1 \mathrm{~h}$, repeat steps a through $e$ and remove die assembly. Note that argon should be introduced $1 \mathrm{~h}$ before proceeding to step b.

$z$. Repeat steps $h$ through $k$ to leave vacuum chamber evacuated. Place run sheets and record charts in appropriate folders.

I. Post-Press Sintering and Pellet Storage

After the pellet is removed from the die insert it is stored in a graphite container for $16 \mathrm{~h}$ or longer (overnight). We have stored pellets for as long as 2 weeks prior to sintering with no deletorious effects. After storage, the pellet is weighed and the dimensions are measured. The pellet is then sintered in flowing $\mathrm{Ar}-\mathrm{H}_{2}{ }^{160}$ for $6 \mathrm{~h}$ at $1000^{\circ} \mathrm{C}$ followed by $6 \mathrm{~h}$ at $1527^{\circ} \mathrm{C}$. Heating and cooling rates are $150^{\circ} \mathrm{C} / \mathrm{h}$. The same Astro furnaces are used for the sintering 
operation as were used for the oxygen-16 exchange and granule seasoning operations. The pellet is loaded, half-buried, in a platinum boat filled with highfired thoria powder. After sintering, the pellet is weighed and the dimensions are remeasured. The volume and density are then calculated. The sintered pellet is then stored in the graphite container until transferred for use. During the sintering operation, the pellet dimensions will shrink by about 0.5 to $0.8 \%$.

During hot pressing, the plutonia is reduced to a stoichiometry of about $\mathrm{PuO}_{1} \cdot 88$. We store the pellet overnight so that it will be reoxidized to $\mathrm{PuO}_{2} \cdot 0$ or nearly so before the dimensioning activities. Similarly, the $\mathrm{Ar}-\mathrm{H}_{2}{ }^{160} \mathrm{Ogas}$ flow is started before the furnace is turned on to ensure a stoichiometry of $\mathrm{PuO}_{2} \cdot 0$ before the pellet is sintered. The use of $\mathrm{Ar}-\mathrm{H}_{2}{ }^{16} 0$ flow gas, of course, precludes back exchange of the material and subsequent increased neutron emission rates. The slow heating and cooling rates are employed to reduce the chance of thermally shocking the pellet. Sintering the pellet in a platinum boat filled with thoria powder prevents thermal stress points that can occur if the pellet comes in direct contact with the platinum.

The effectiveness of these operations is indicated by the fact that flow pellets form surface cracks during sintering and by the impact test results. To date, 12 LASL GPHS pellets encapsulated in iridium containers have been impacted. All impact tests were successful and in no case did the fuel breach the container material.

1. Equipment. The equipment used for the sintering and weighing operations has been described above. Gas flows are the same as those used for the oxygen-16 exchange and granule seasoning operations. Note that only the Astro furnaces are used for the sintering operations. The platinum boat is filled to about $80 \%$ capacity with thoria powder previously sintered at $2000^{\circ} \mathrm{C}$. The pellet storage container is shown on drawing $26 \mathrm{Y}-79829 \mathrm{Cl}$. The measurement stand is shown on drawings 26Y-79594 D1 and 26Y-79594 D2. Each of these drawings i.s presented in the appendix.

2. Procedure.

a. Transfer the die assembly to the pellet storage and dimensioning area.

b. Remove the endcaps and the susceptor. Remove 1 punch. Note that if the insert is to be used for a second pressing, the pellet must be pushed out of the end of the insert farthest from the bore region to be used for the second pressing.

c. Place insert on Carver press and use stainless steel rod to push out pellet. Secure pellet with stainless steel forceps before it can fall to the press platen.

d. Place pellet in graphite storage container and leave it there for $16 \mathrm{~h}$ (overnight).

e. Weigh the pellet. Check the micrometer with the standard block and measure the pellet dimensions. Record the weight and dimensions.

f. Transfer pellet to furnace glovebox. Place pellet in platinum boat filled with thoria so that pellet is half-buried with endcaps facing the furnace ends.

g. Place boat in Astro furnace, seal furnace, position thermocouples and initiate gas flow.

h. Check that correct chart is on the DATA TRACK programmer. Begin programmed run cycle.

i. When sintering cycle is complete, remove boat from furnace. Remove pellet from boat and brush off any thoria particles with a stainless steel brush. 
Put the pellet back into the graphite storage container and transfer it to the dimensioning glovebox.

$j$. Weigh the sintered pellet and measure the diameter and length. Record the weight and dimensions. Note the surface condition of the pellet.

k. Store pellet in graphite storage container until it is needed.

J. Encapsulation and Decontamination of Iridium Capsules

The sintered pellet is loaded into an iridium-tungsten alloy capsule $(0.3$ wt\% W). The capsule drawing, $26 Y-79902$ D1, is presented in the appendix. The capsules are fabricated and the vents and weld shields are installed at MF. The interior dimensions of the capsules are such that the capsules will accept a pellet $27.94-\mathrm{mm}$-diam by $27.94-\mathrm{mm}-1$ ong with a $0.78-\mathrm{mm}$ standoff. The capsule is welded by standard gas-tungsten arc techniques and then cleaned. The welding fixtures and procedures will be described in a later report. 7 only the cleaning operation will be described here.

The welded capsules are cleaned by successive immersions in 3 acid solutions $\left(5 / 2 / 2\right.$ of $\left.\mathrm{H}_{2} \mathrm{O} / \mathrm{HNO}_{3} / \mathrm{HF}\right)$ followed by immersions in distilled water and finaliy in ethanol. The heat given off by the capsules is sufficient to preclude additional heating of the acid baths. All capsules are cleaned to fewer than 50 counts per second per capsule (swipe) before being transferred to the test area.

1. Equipment. The capsule cleaning operation requires distilled water, reagent grade hydrofluoric and nitric acid, polyethylene beakers, cheesecloth and nickel-plated forceps.

2. Procedure. Since the cleaning operation involves the use of acjd and is performed in a hood, it is imperative that all personnel wear safety glasses and that a health physics monitor be present at al1 times.

a. Mix $100 \mathrm{ml}$ of $\mathrm{H}_{2} \mathrm{O}, 40 \mathrm{ml}$ of $\mathrm{HNO}_{3}$ and $40 \mathrm{ml}$ of $\mathrm{HF}$ in a clean $450-\mathrm{ml}$ polyethylene beaker. Be sure to pour the acid into the water.

b. Repeat until 3 acid beakers have been prepared.

c. Pour $180 \mathrm{ml}$ of distilled water into a fourth beaker.

d. Pour $180 \mathrm{ml}$ of pure ethanol into a fifth beaker.

e. Use the nickel-plated forceps to remove capsule from airlock and place it in the first acid beaker. Keep capsule immersed for 2 to $3 \mathrm{~min}$.

$f$. Remove capsule from first acid beaker, wipe with wet cheesecloth (water) and place capsule in second acid beaker. The heat from the capsule will quickly dry the cheesecloth.

g. Repeat step $f$, moving capsule to third acid veaker.

h. Continue successive immersions in water and ethanol, 2 to 3 min each.

$i$. After immersion in ethanol, capsule should have fewer than 50 counts per second (swipe). If swipe count is greater, replace capsule in third acid bath and repeat immersions.

$j$. When completed dispose of cheesecloth in proper can, pour acid and water into labelled polyethylene bottle. Repeat for the ethanol. Do not mix ethanol and nitric acid.

K. Flowsheet Summary

The flowsheet described in this report has been used to fabricate 25 GPHS fuel pellets at LASL. The sintered dimensions for these pellets are listed in Table VIII. These pellets have a very homogeneous microstructure, an excellant response to impact and a higher density than previously used fuel forms. 
TABLE VIII

LASL 62.5-W SIZE GPHS PELLETS

SINTERED DIMENSIONS

\begin{tabular}{|c|c|c|c|c|}
\hline No. & $\begin{array}{c}\text { Diam } \\
\text { (Inches) }\end{array}$ & $\begin{array}{l}\text { Length } \\
\text { (Inches) }\end{array}$ & $\begin{array}{c}\text { Weight } \\
(\mathrm{g})\end{array}$ & $\begin{array}{l}\text { Density } \\
(\% \text { TD })\end{array}$ \\
\hline $\begin{array}{lc}\text { GP } & 4^{\mathrm{a}} \\
\mathrm{GP} & 7 \\
\mathrm{GP} & 11\end{array}$ & $\begin{array}{l}1.097 \\
1.094 \\
1.090\end{array}$ & $\begin{array}{l}1.069 \\
1.106 \\
1.079\end{array}$ & $\begin{array}{l}152.396 \\
152.374 \\
152.342\end{array}$ & $\begin{array}{l}85.4 \\
82.9 \\
85.6\end{array}$ \\
\hline $\begin{array}{ll}\text { GP } & 12 \\
\text { GP } & 14 \\
\text { GP } & 15 \\
\text { GP } & 16 \\
\text { GP } & 17 \\
\text { GP } & 18 \\
\text { GP } & 19 \\
\text { GP } & 21 \\
\text { GP } & 22 \\
\text { GP } & 23 \\
\text { GP } & 24 \\
\text { GP } & 25 \\
\text { GP } & 26 \\
\text { GP } & 27 \\
\text { GP } & 29 \\
\text { GP } & 30 \\
\text { GP } & 31 \\
\text { GP } & 32 \\
\text { GP } & 33 \\
\text { GP } & 34 \\
\text { GP } & 35 \\
\text { GP } & 36\end{array}$ & $\begin{array}{l}1.092 \\
1.089 \\
1.089 \\
1.086 \\
1.089 \\
1.094 \\
1.090 \\
1.085 \\
1.088 \\
1.088 \\
1.088 \\
1.088 \\
1.085 \\
1.090 \\
1.085 \\
1.086 \\
1.088 \\
1.094 \\
1.083 \\
1.089 \\
1.086 \\
1.088 \\
\end{array}$ & $\begin{array}{l}1.096 \\
1.094 \\
1.089 \\
1.100 \\
1.099 \\
1.082 \\
1.096 \\
1.083 \\
1.083 \\
1.091 \\
1.090 \\
1.100 \\
1.088 \\
1.086 \\
1.096 \\
1.088 \\
1.093 \\
1.093 \\
1.079 \\
1.081 \\
1.093 \\
1.086 \\
\end{array}$ & $\begin{array}{l}152.299 \\
152.433 \\
152.386 \\
152.294 \\
152.420 \\
152.392 \\
152.462 \\
152.404 \\
152.405 \\
152.446 \\
152.399 \\
152.383 \\
152.345 \\
152.389 \\
152.412 \\
152.323 \\
152.418 \\
152.351 \\
152.397 \\
152.280 \\
152.356 \\
152.307 \\
\end{array}$ & $\begin{array}{l}83.9 \\
84.7 \\
85.1 \\
84.5 \\
84.3 \\
84.8 \\
84.4 \\
86.1 \\
85.7 \\
85.0 \\
85.1 \\
84.3 \\
85.7 \\
85.1 \\
85.1 \\
85.6 \\
84.8 \\
84.0 \\
86.7 \\
85.6 \\
85.1 \\
85.4 \\
\end{array}$ \\
\hline & $\begin{array}{r}1.088 \\
\pm 0.003\end{array}$ & $\begin{array}{r}1.090 \\
\pm 0.006\end{array}$ & $\begin{array}{l}152.377^{\mathrm{b}} \\
\pm 0.057\end{array}$ & $\begin{array}{r}85.0 \\
\pm 0.7\end{array}$ \\
\hline
\end{tabular}

a Numerous adjustments were made to hot-press after pressing each of the first 3 pellet lots. Dimensions for lots 4,7 , and 11 are not included in the averages.

bStandard deviation in weight corresponds to \pm 0.02 watts. 
The flowsheet is similar, as is the equipment employed, to that previously transmitted to SRP for the fabrication of homogeneous MHW spheres. This LASL flowsheet for GPHS pellets has also been transmitted to SRP and SRL. We would expect that the production pellets made at SRP should be the same as the pellets made at LASL, if the LASL flowsheet is adhered to. Any changes in the flowsheet could, of course, result in changes in the fuel microstructure and stability with resultant deletorious effects on the response of the fuel to thermal shock and impact.

\section{FINAL FUEL SPECIFICATIONS}

The final specifications for the GPHS fuel pellets are based on the design criteria for the GPHS heat source, the analytical data listed in Section III, above, and on the LASL experience fabricating pellets with this flowsheet.

\section{A. Fuel Feed Powder}

The feed material shall consist of pure plutonia powder produced at SRP by calcining plutonium oxalate precipitated under the following conditions.

1. Oxalic Acid. $1.5 \pm 0.2 \mathrm{M}$ reagent grade.

2. Plutonium Concentration. $4-6 \mathrm{~g} / \mathrm{l}$.

3. Precipitation Temperature. $35 \pm 5^{\circ} \mathrm{C}$.

B. Isotopic Composition

The feed material will be enriched at $83.5 \pm 0.3$ at.\% $238 \mathrm{Pu}$ so as to produce $0.415 \mathrm{~W} / \mathrm{g}$ when first made.

C. Purity

The purity specifications for the feed powder and subsequent fuel pellets will be those listed for MHW fuel in Table III, column 2, of this report.

D. Neutron Emission Rate

The neutron emission rate for the sintered fuel pellets will be less than $8000 \mathrm{n} / \mathrm{s}-\mathrm{g} 238 \mathrm{pu}$.

E. Fabrication Flowsheet

The fabrication flowsheet used to process the feed material and make the GPHS pellets will be that described in this report.

F. Fuel Charge and Thermal Inventory

The graphite dies used for hot pressing the pellets will be charged with $152.44 \pm 0.01 \mathrm{~g}$ of GROG-type feed granules seasoned at $1100 \pm 15^{0}(60 \mathrm{wt} \%)$ and $1600 \pm 15^{\circ} \mathrm{C}(40 \mathrm{wt} \%)$. The thermal inventory for the pellets will be $63.0 \mathrm{~W}$ or greater as pressed.

G. Fuel Dimensions

The sintered dimensions for the fuel pellets will be $27.64 \pm 0.15-\mathrm{mm}$-diam by $27.69 \pm 0.25-\mathrm{mm}-1$ ength. The density will be set by the dimensions and the charge weight and will be $85 \pm 1 \%$ TD. 
H. Fuel Appearance

The endcaps shall be radiused as per LASL drawing 26Y-79750 D1. Only integral pellets shall be loaded for welding.

\section{REFERENCES}

1. T. K. Keenan, R. A. Kent, and R. W. Zocher, "The Relationship of Fabrication Parameters to Selected Properties of $238 \mathrm{PuO}_{2}$ Radioisotopic Fuels, I. Dimensional Changes, Stoichiometries, and Microstructureal Features," Los Alamos Scientific Laboratory Report LA-5622-MS (May, 1974).

2. J. J. Petrovic, S. S. Hecker, C. C. Land, and D. L. Rohr, "Mechanical Properties of $238 \mathrm{PuO}_{2}$," Los Alamos Scientific Laboratory Report LA-6529 (Apri1, 1977).

3. T. K. Keenan, R. A. Kent, R. N. R. Mulford, and M. W. Shipe, "Data Sheets for PPO Radioisotopic Fuel, "Los Alamos Scientific Laboratory Report LA5160-MS-Rev. 1 (December, 1973).

4. J. F. Andrew, R. W. Zocher, and R. A. Kent, "Thermal Expansion of $238 \mathrm{PuO}_{2}$," Los Alamos Scientific Laboratory Report LA-6232-MS (February, 1976).

5. R. A. Kent and R. W. Zocher, "Heat Transfer in 238Pu0 2 Spheres," Los Alamos Scientific Laboratory Report LA-6340-MS (May, 1976).

6. MRC Document 1-14813, Apri1 4, 1972, "Multi-Hundred Watt Fuel Specification."

7. E. Brandon, Los Alamos Scientific Laboratory, unpublished work, 1979.

APPENDIX

PROCESSING EQUIPMENT DRAWINGS FOR LASL CPHS PROCESSING FLOWSHEET

This appendix includes the following drawings:

\begin{tabular}{|c|c|c|c|}
\hline $26 Y-79234$ & $\mathrm{Cl}$ & $26 Y-79204$ DI & $26 Y-79355$ \\
\hline $26 Y-79394$ & D1 & $26 Y-79673$ D1 & $26 Y-79594$ \\
\hline $26 Y-79394$ & $\mathrm{C} 2$ & $26 Y-79673$ D2 & $26 Y-79594$ \\
\hline $26 Y-74491$ & DI & 26Y-79750 וס & $26 Y-79829$ \\
\hline $26 Y-74872$ & DI & $26 \mathrm{Y}-74791 \mathrm{Cl}$ & $26 Y-79902$ \\
\hline
\end{tabular}




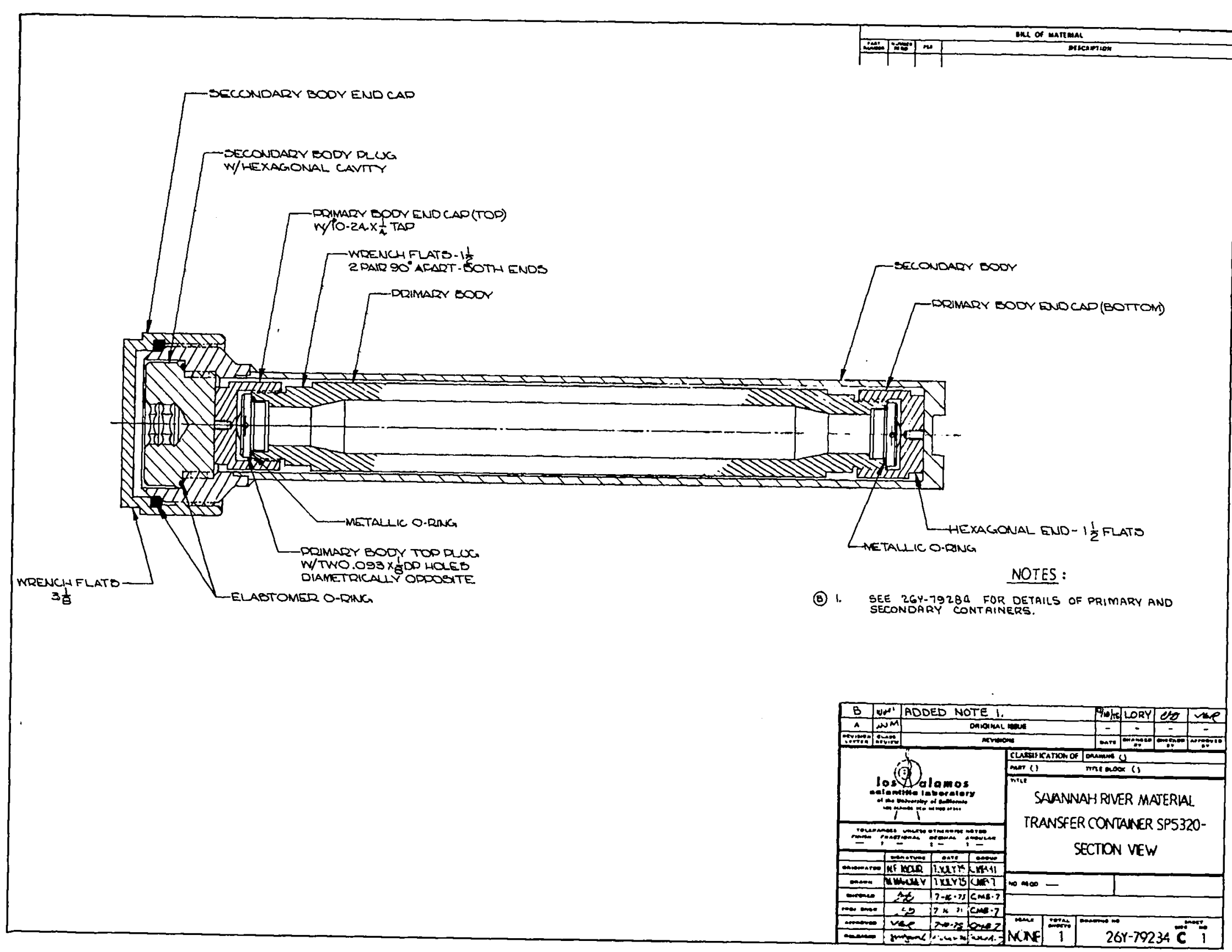




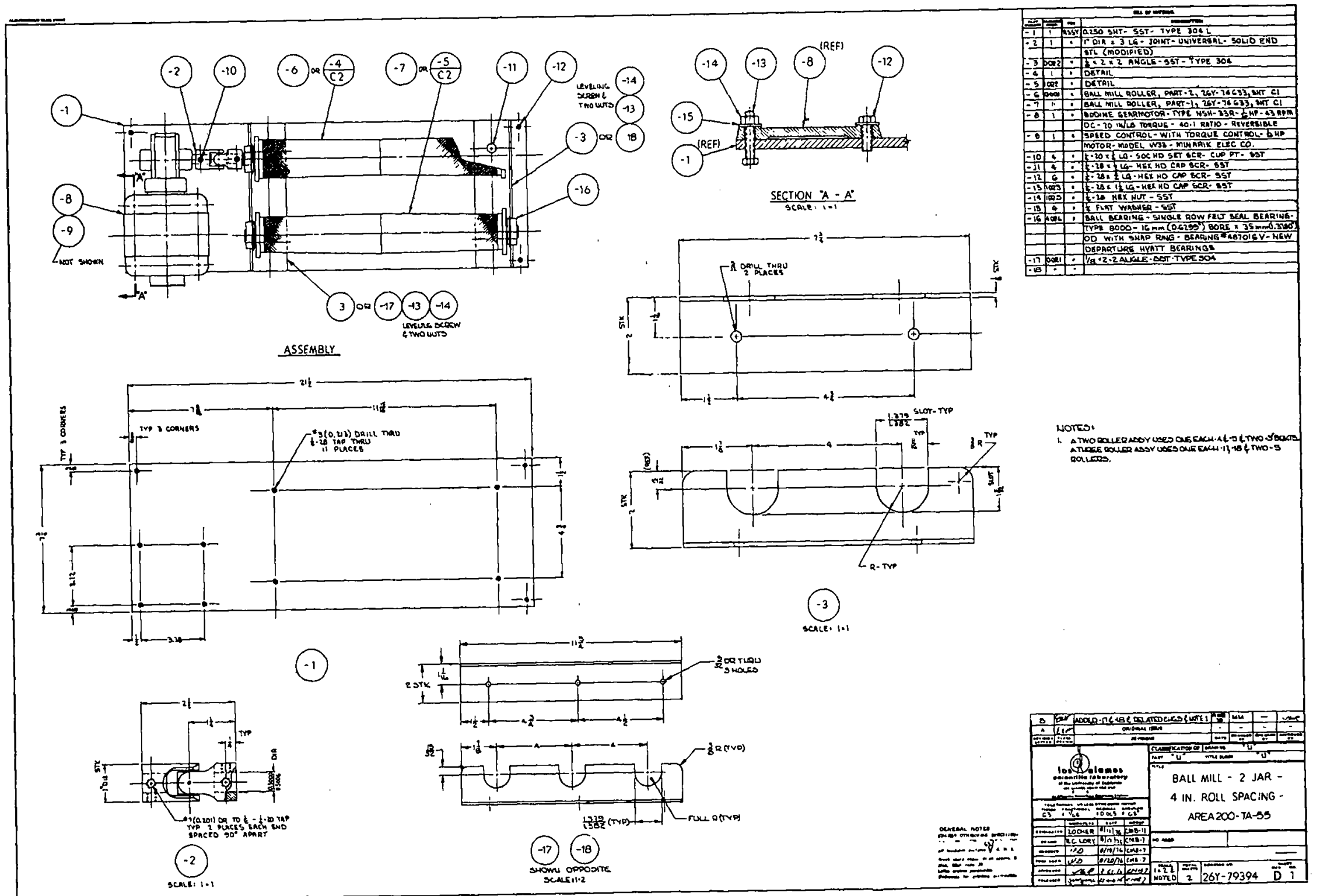

$\omega$ 


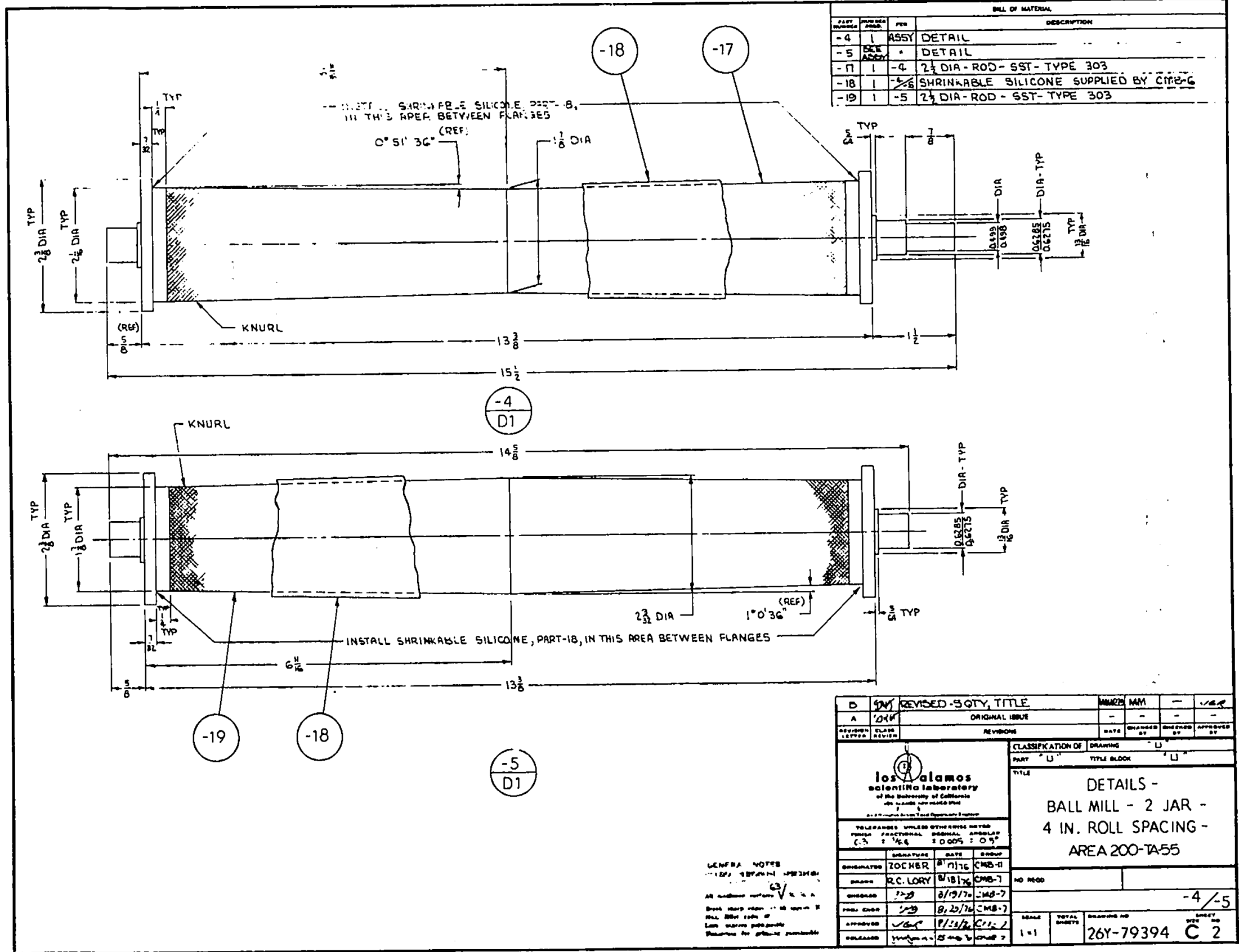




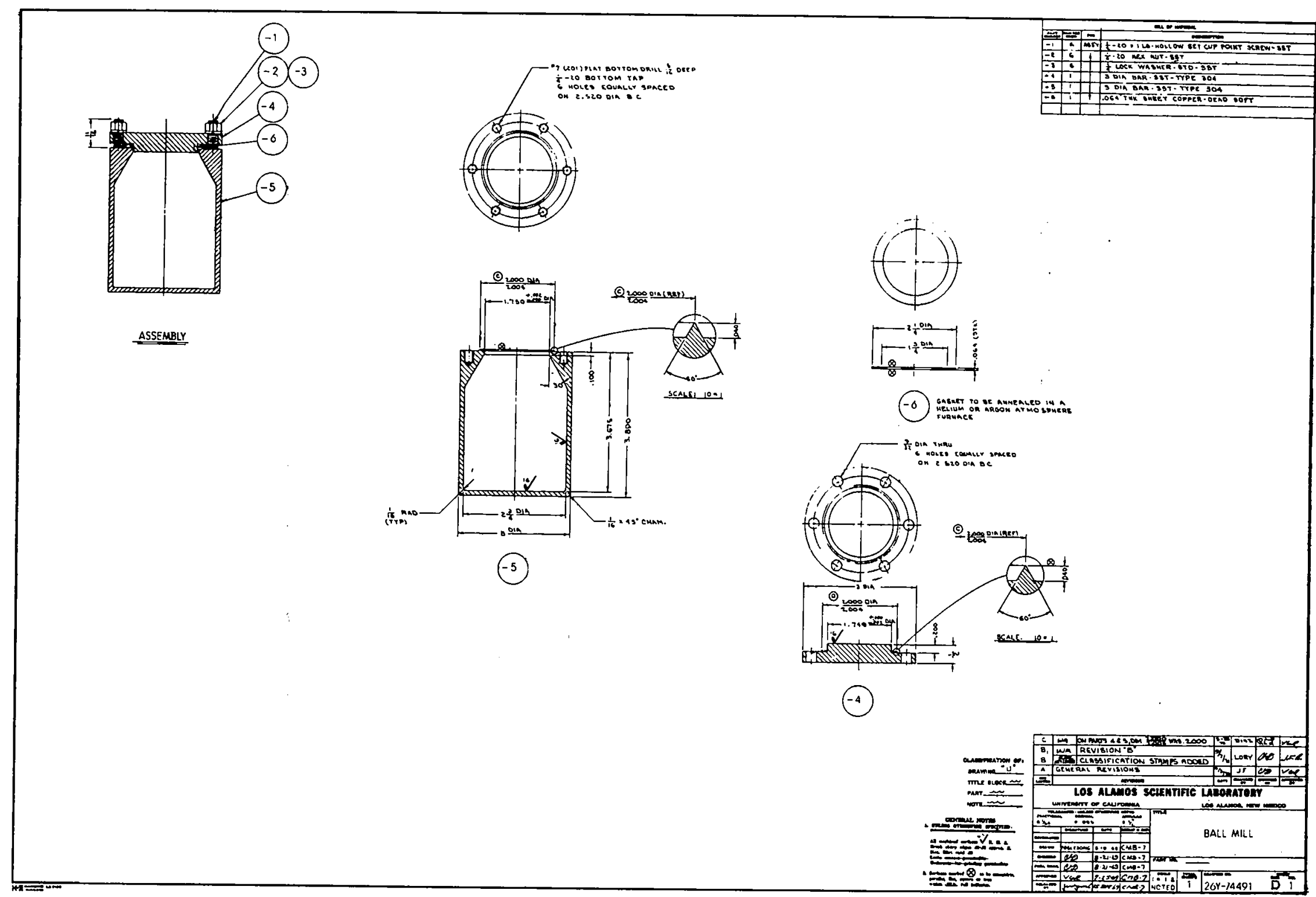




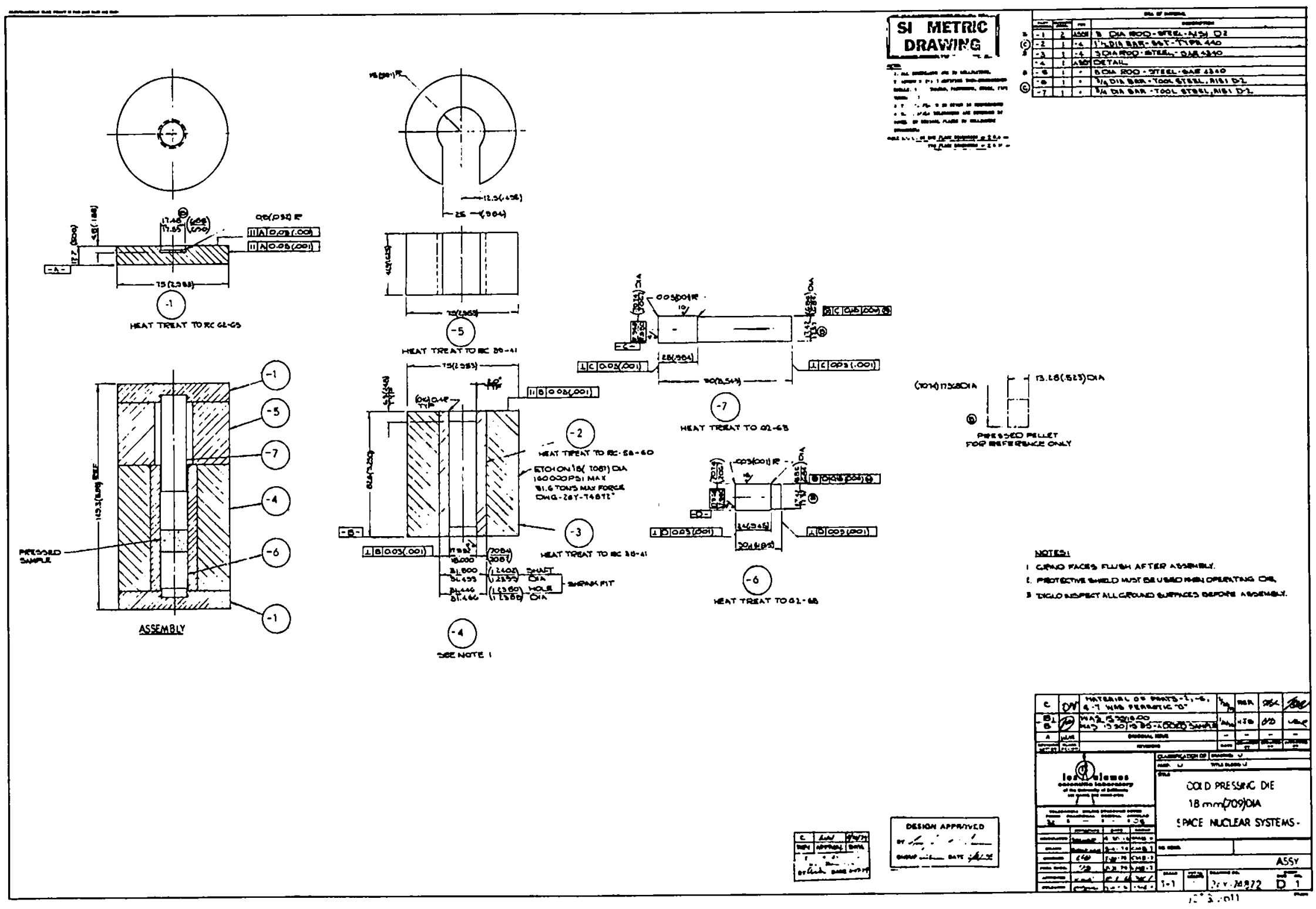




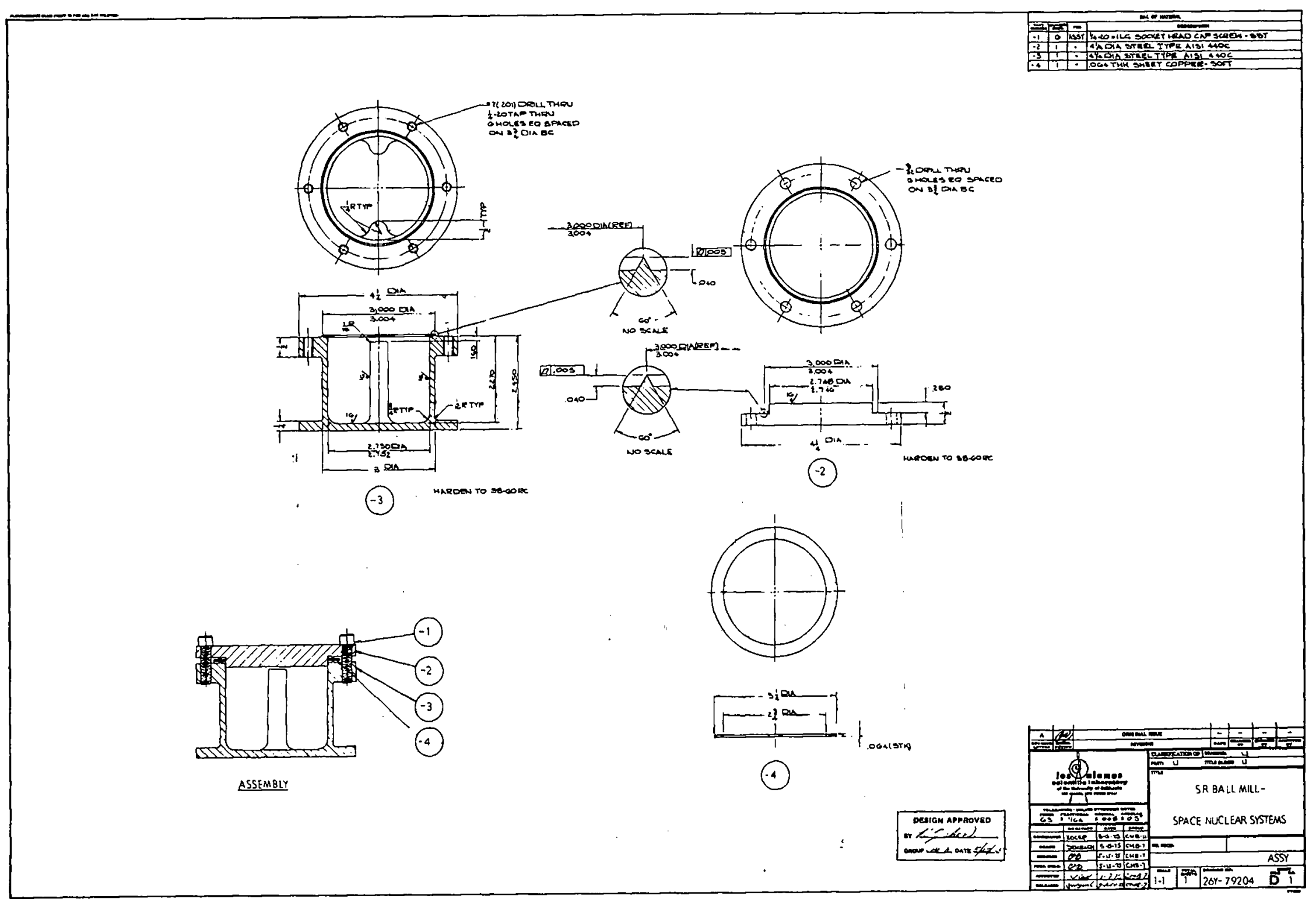




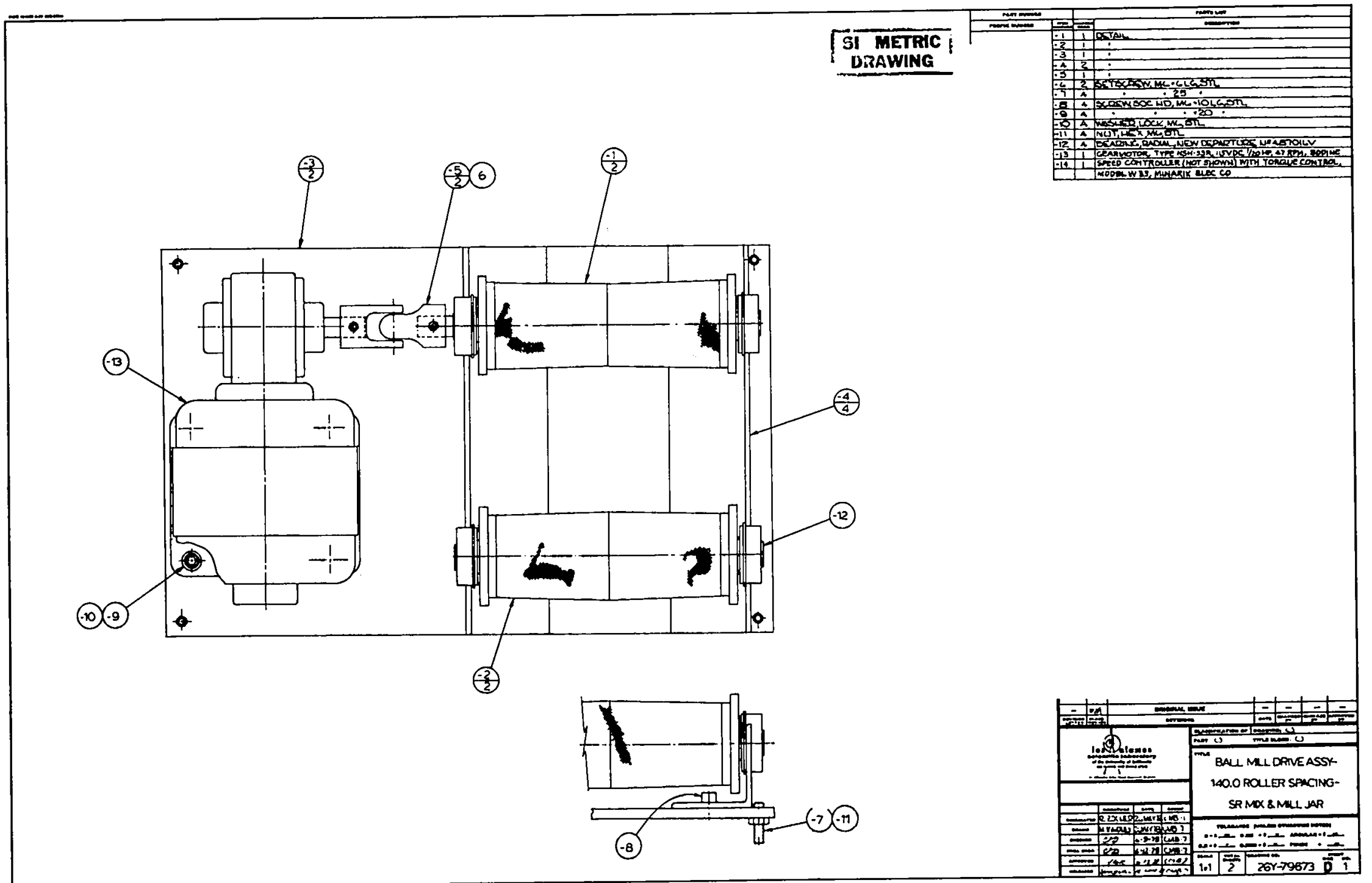




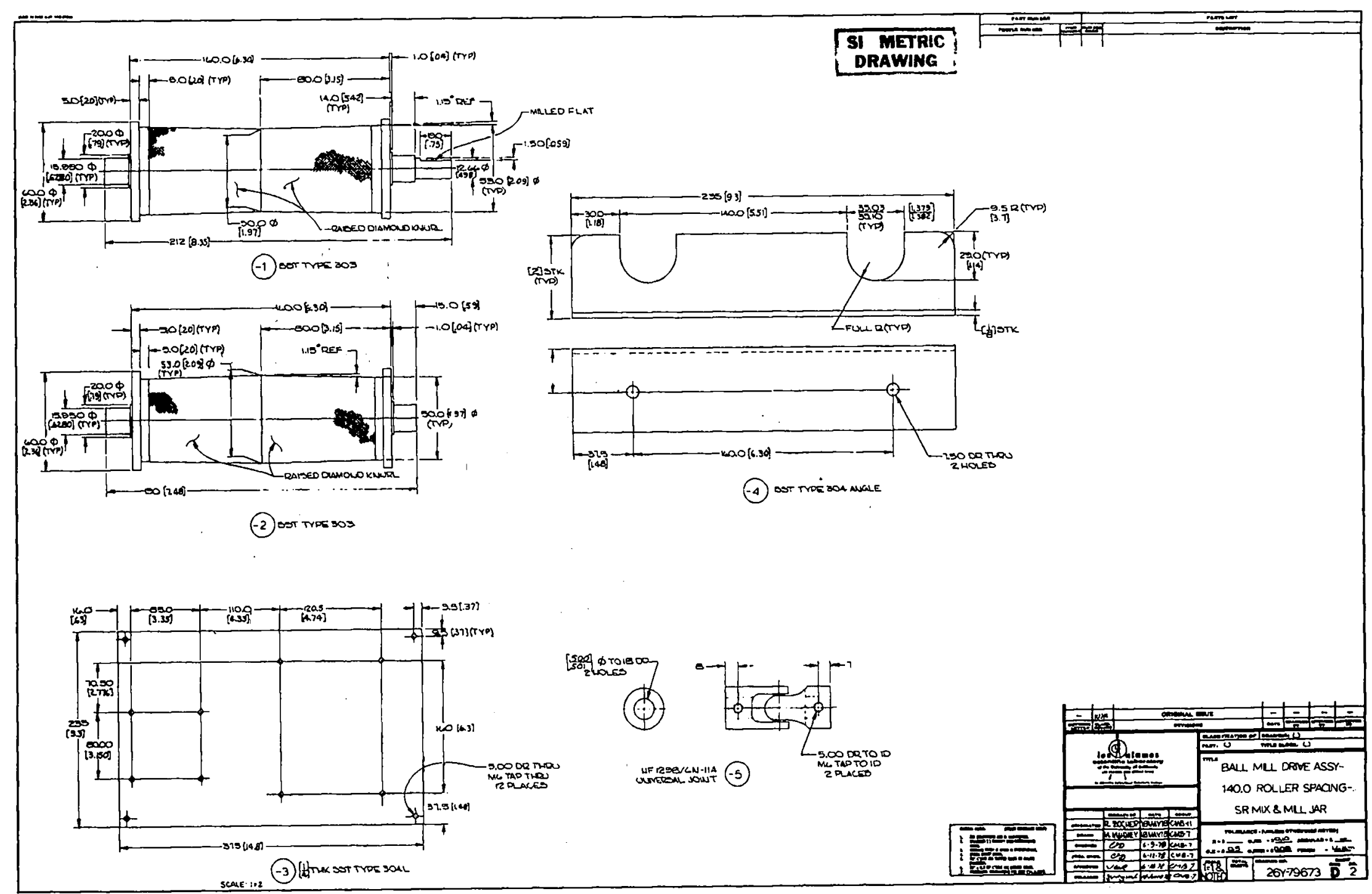




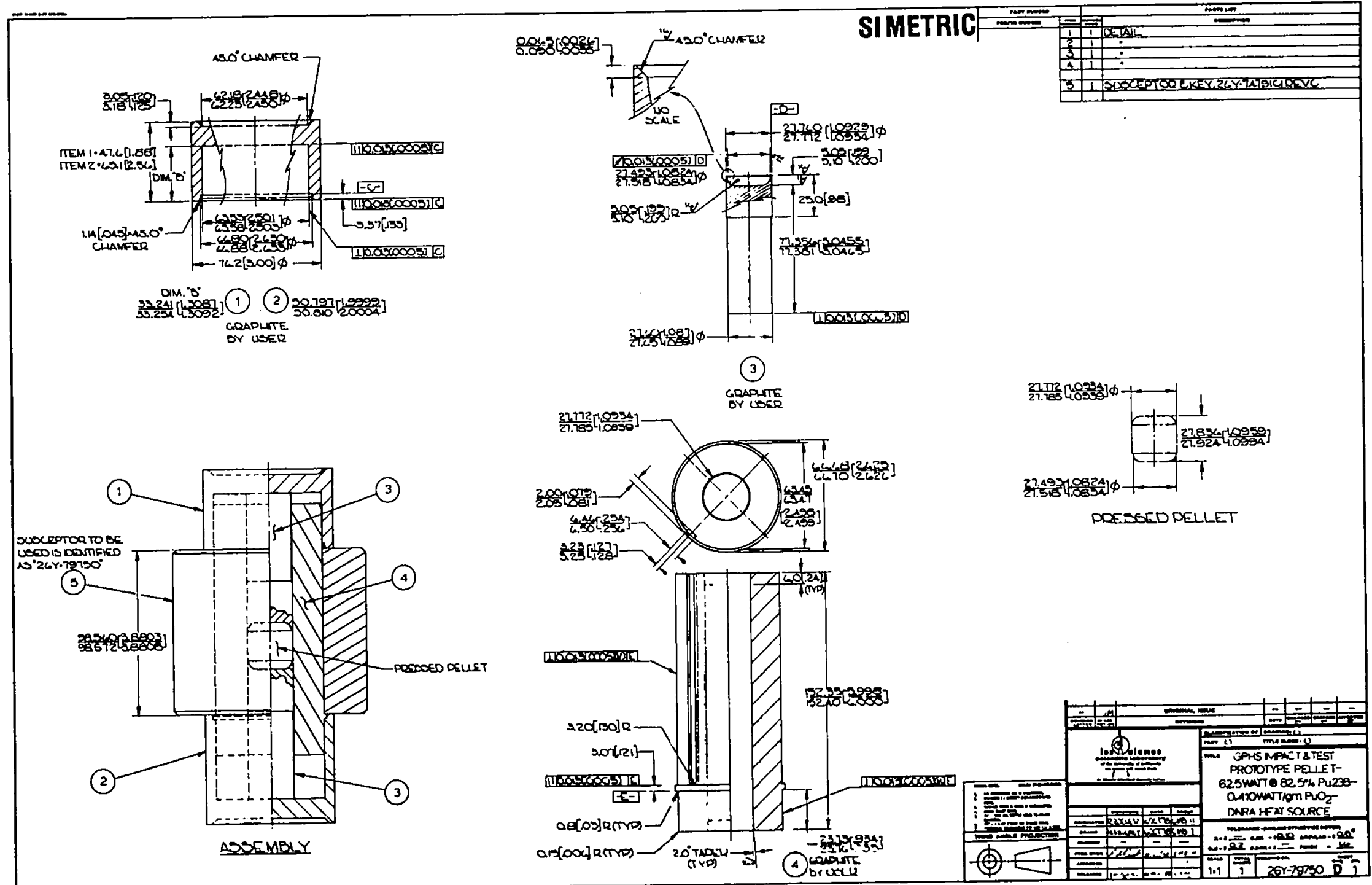




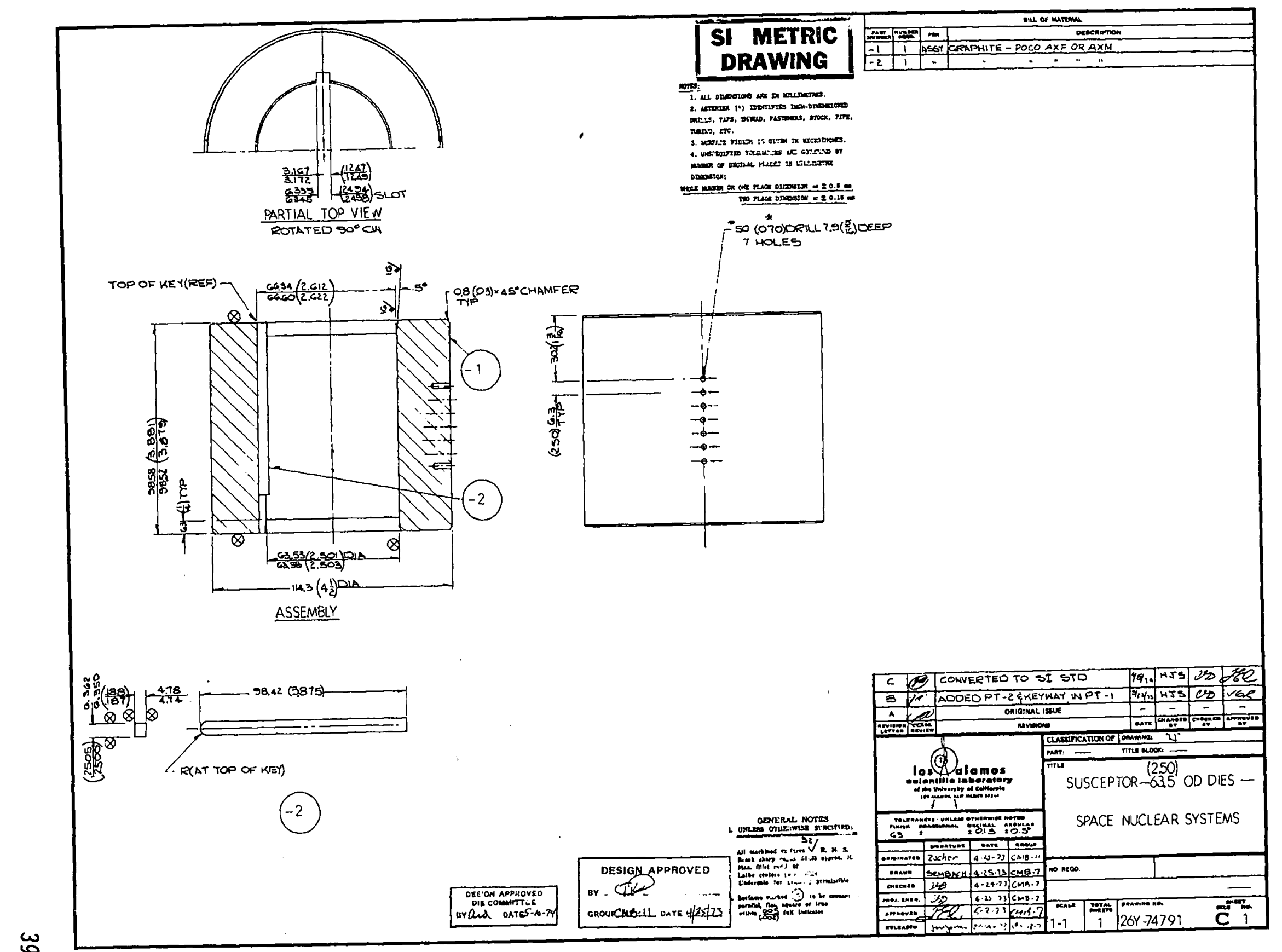




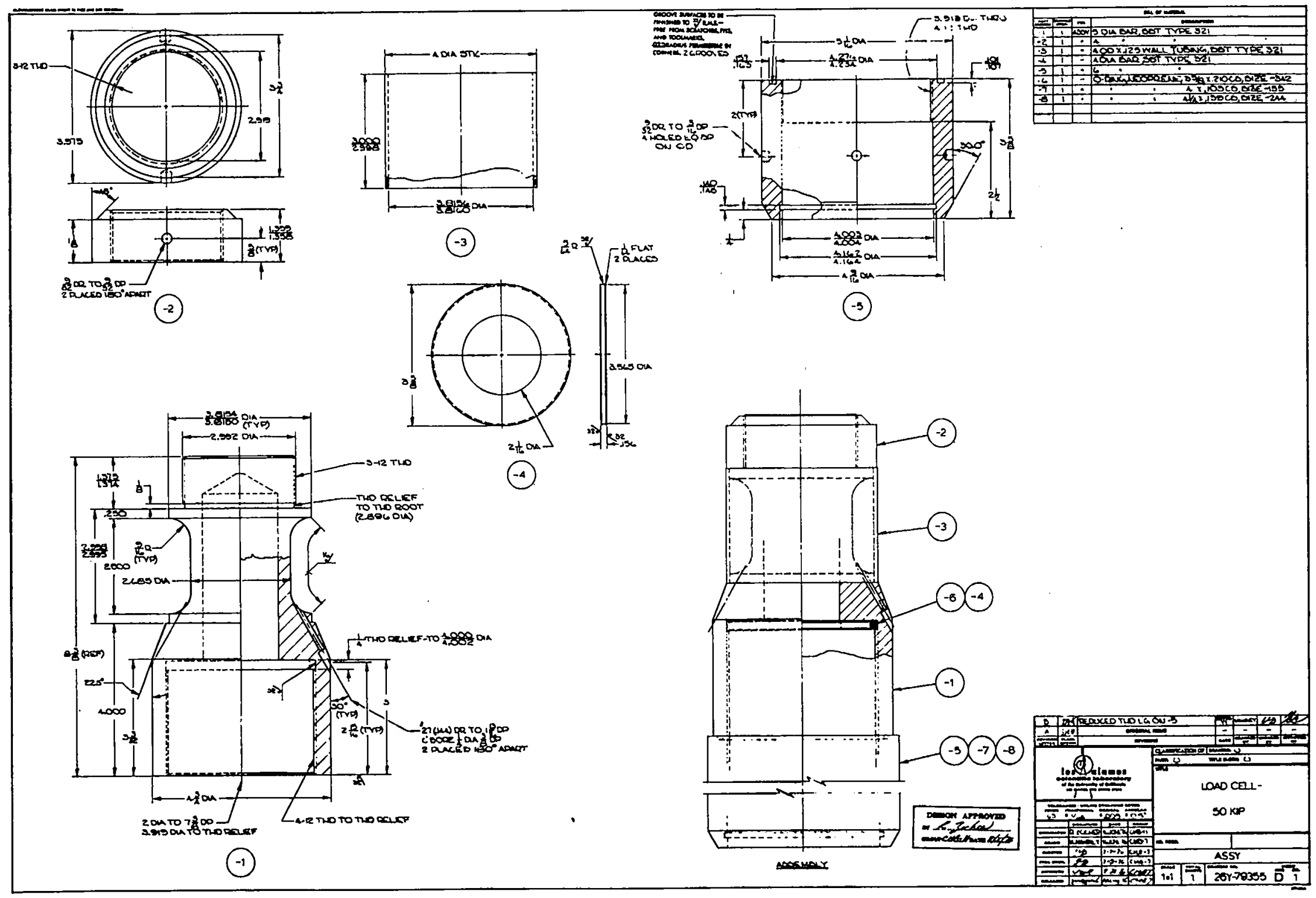




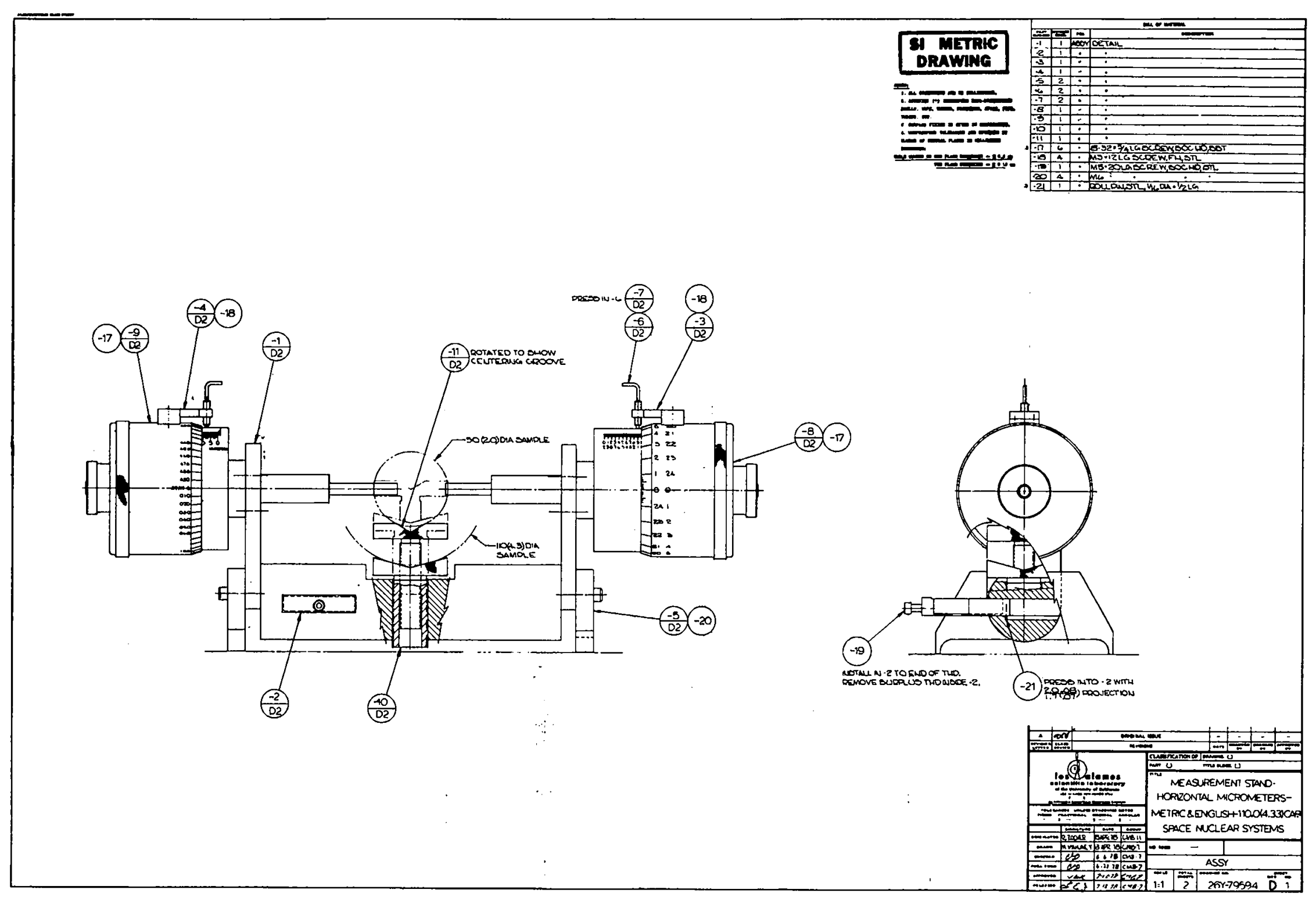




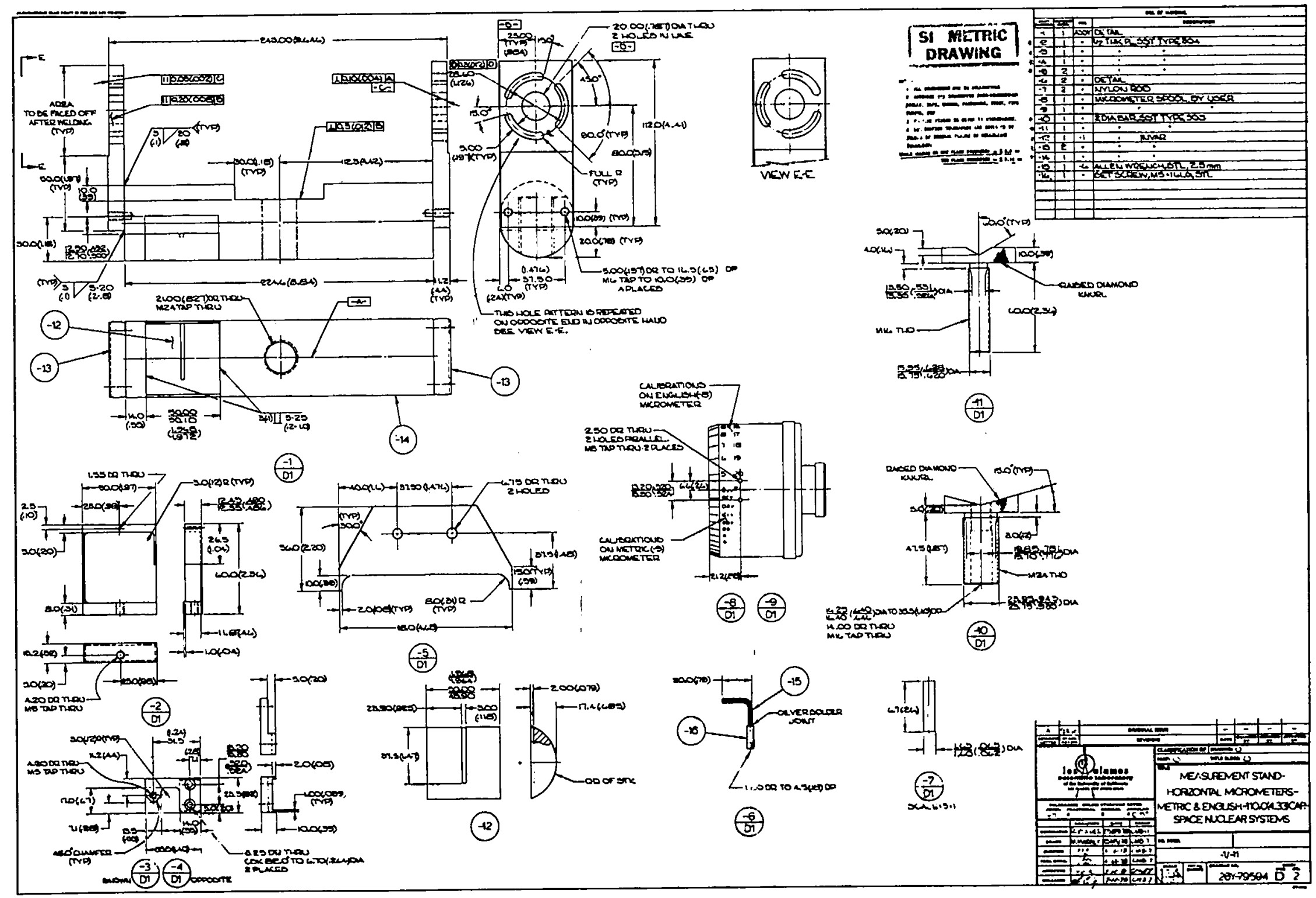




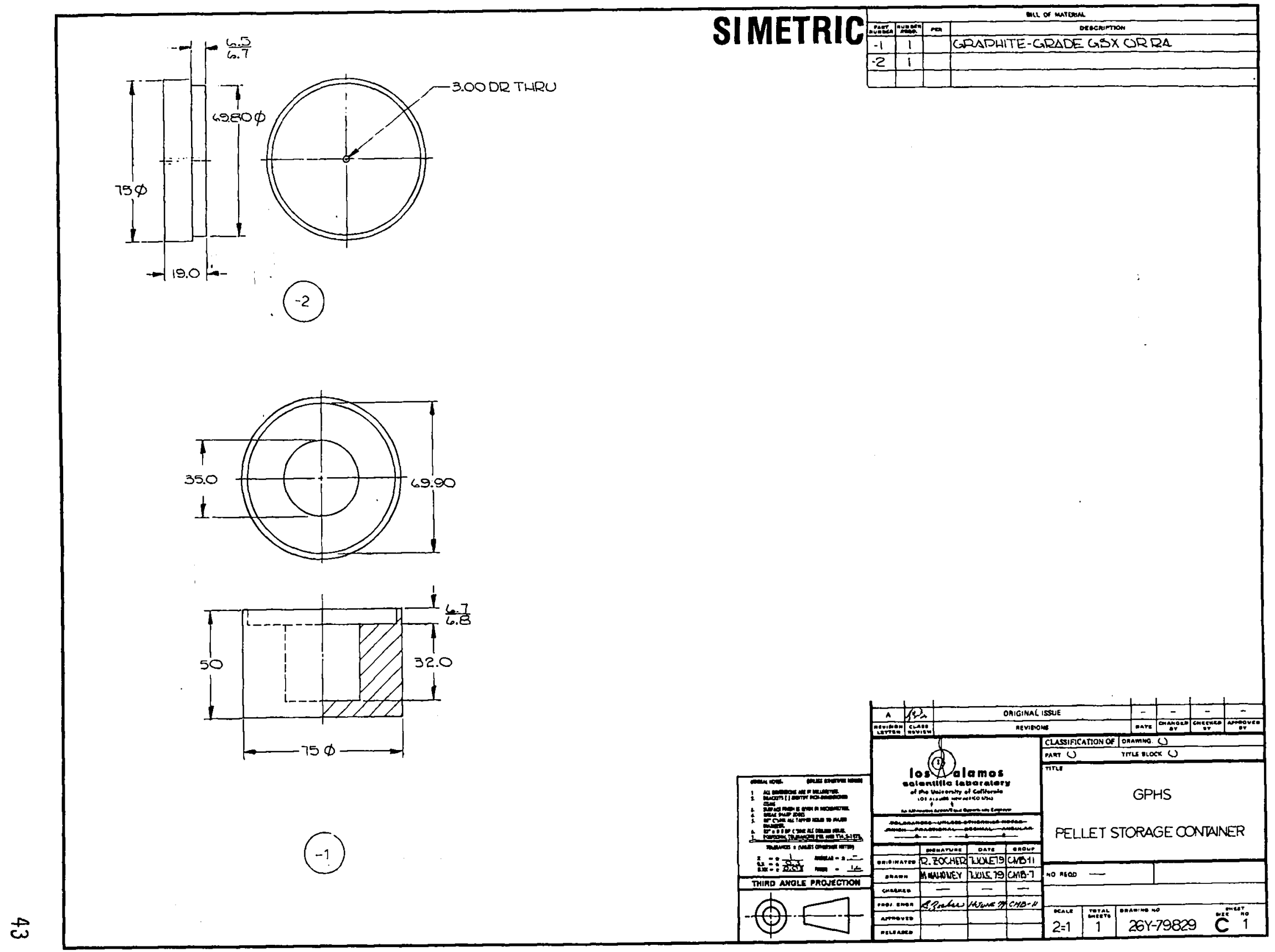




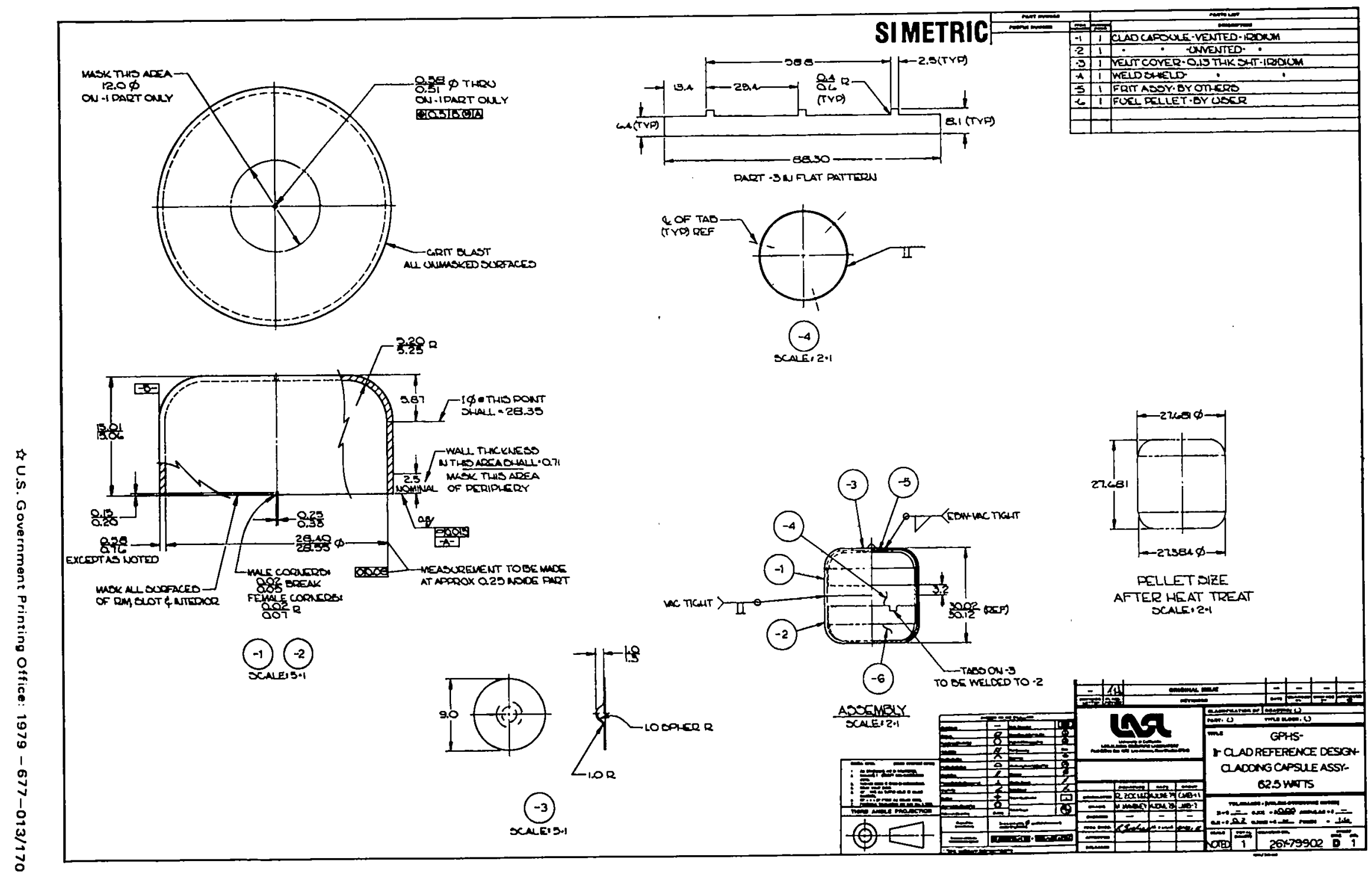


Printed in the United Stutes of Ameris. Avaitahle from Nutionsl Tuchniwal Information Servici

LS Depurtiment of Commeric

$$
5285 \text { Purt Koyal Road }
$$

Sprinetixld. VA 22161

Mictorithe $\$ 3.00$

$\begin{array}{llllllllll}001.025 & 4.00 & 126-150 & 7.25 & 251-275 & 10.75 & 376-400 & 13.00 & 501.525 & 15.25 \\ 026-050 & 4.50 & 151-175 & 8.00 & 276-300 & 11.00 & 401-425 & 13.25 & 526.550 & 15.50 \\ 051.075 & 5.25 & 176-200 & 9.00 & 301-325 & 11.75 & 426-450 & 14.00 & 551-575 & 16.25 \\ 076.100 & 6.00 & 201.225 & 9.25 & 326.350 & 12.00 & 451-475 & 14.50 & 576600 & 16.50 \\ 101-125 & 6.50 & 226-250 & 9.50 & 351-375 & 12.50 & 476.500 & 15.00 & 601-41 & \end{array}$

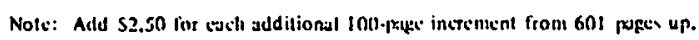

